\title{
46.1394
}

OF NL/NUAEG-16

\section{A Model of lodine Transport and Reaction Kinetics in a Nuclear Fuel Reprocessing Plant}

\author{
Wallace :- avis, Jr.
}

Prepared for the U.S. Nucle ir Regulatory Commission Office of Nuclear Material Safety \& Safeguards Under Interagency Agreemen: ERDA 40-549-75 


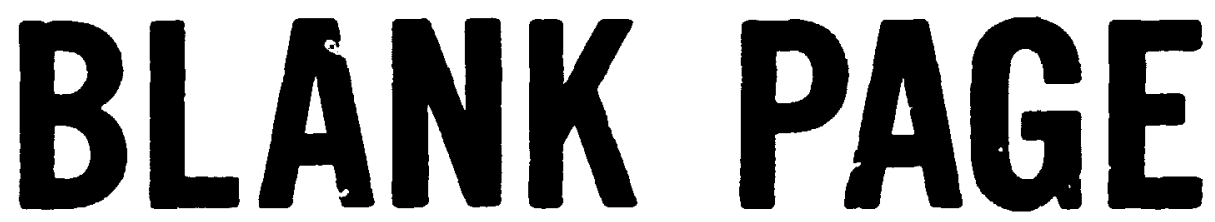


Printed in the United States of America. Available from Hational Tecnnical Information Service

U.S. Department of Commerce

5285 Port Royal Road, Springfield, Virginia 22161

Price: Printed Copy \$5.00; Microfiche $\$ 3.00$

In : repoit was prepared as an acrount of work sponsored by the United Staies Government Neither the United States nor the Energy Research and Devetopment Administration United States Nuclear Regulatcry Commission. nor any of their employees. nor any of their coniracturs subcontractors, or their employees. makes ar. i warraniy. express or implied. or assumes any legal liability or responsib:lity for the accuracy. completeness or usefulness of any information. apparatus. product or prixess disclosed. or represents inat its use would not infringe privately owned rights 
ORKL/RUREG-16

Dist. Category UC-4

Contract No. W-7405-eng-26

ChIAICal TEChrology DIVISIOA

A MODEL OF IODINE TRANSPORT AND REACTIOA XINETICS

IN A RUCLEAR FUEL REPROCESSING PLANT

Uallace Davis, Jr.

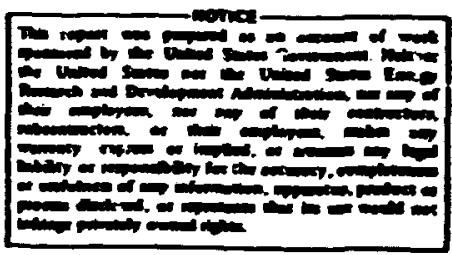

Completion date: May 1977

Publication date: August 1977

Prepared for the

J.S. Nuclear Regulatory Comission

office of Nuclear Material Safety \& Safeguards

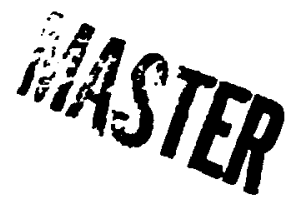

Under Interagency Agreement ERDA 40-549-75

OAK RIDGE NATIONAL LABORATORY

Oak Ridge, Tennessee $\mathbf{3 7 8 3 0}$

operated by

UNION CARBIDE CORPORATION

for the

ENERGY RESEARCH AND DEVELOPMERT ADMINISTRATION 
Coirreirs

Page

Abstract . . . . . . . . . . . . . . . . . . 1

1. Introduction ...................... 2

2. The Hodel and Definftions ................. 4

3. Experfmental Data and Assuptions Concerning Flows ....... 9

4. Examples of Calculations ................. 16

5. Discussion and Conclusions ................. 33

6. References ...................... 35

7. Appendices ...................... . . . . 39

A. Evaluation of Iodine flow Rates . . . . . . . . . 39

B. Definitions and Values of Parameters . . . . . . . . . 43

C. Decomposition of Matrix Equatior (29) . . . . . . . . 46 
A MDE OF IODINE TRAISPORT AN REACTION RINETICS

II A ROCLEAR FUEL REPROCESSIIG PLAST

Sallace Davis, Jr.

\section{ARSTRACT}

A wodel is presented to des,ribe the time-dependent flow and retention of stable lodine isctopes and, additionally. the extent of radioactive decay of ${ }^{131} 1$ in a nuclear fuel reprocessing plant. The plant, which is sinflar to, but slightly nore complex than, Allied-General Nuclear Services'plant at Barmel1, South Carolina, consists of 16 units of equipment such as a voloxidizer or graphite burner, fuel dissolver, solvent extractors, storage tanks, vaporizers, primary lodine sorbers, and silver zeolite. The rate of accumulation of bulk and radioactive lodine in these units and in the enviroment is described in terms of two sets of 19 differential equations that contain paraneters representing experinental data, including flow rates that are functinns of physical or chenical kinetics in each process unit. In the absence of experinental data, the ruaction rates were assumed to obey first-order kinetics with individual tine constants related to estinates of unit capacity for lodine. Isotopic exchange equilibriu is assumed to be maintained in all units.

Based on the meager experimental data and "reasonable" values of bulk-iodine retention times for use in the kinetic processes, reasonable time-dependence of lodine retention factors (RPs) [alternatively designated as decontamination factors (DFs) or confinement factors (CPs)] by the plant has been calculated. In particular, RFs for a new plant in excess of $10^{6}$ fur stable lodine and 12 I decrease to the range of $10^{3}$ to $10^{2}$ as plant operating times exceed 50 to 100 days. The RPs for ${ }^{13}$ I also decrease intisily, for a period of $\sim_{10}$ days, but then increase by several orders of magnitude due to radioactive decay and isotopic exchange. Generally, the RPs for ${ }^{131}$ I exceed those for stable lodine by factors of $10^{4}$ or larger, depending on the operating time and on many other variables.

The computer programs written to solve the two sets of 26 mass flow rates and to integrate the two sets of 19 differential equations can easily be modified to utilize experimental data which will be obtained in the future, including data that might demonstrate one or more of the rate processes not to be firstorder. 


\section{Inmoductios}

Redlanctive lodine isotopes, both short-lived ${ }^{131}$ I (hali-1ife of 8.05 days) and the long-1ived ${ }^{129}$ I (helf-1ife of 16 ailion years), are generated in molear fuels; very anall mounts will be discharged to the enviroment both at the reactors, where they are forned, and at fuel reprocessing plants, whe they wil be encapsulated for peranent storage. The Enviromental Protection Agency has Isoved 1,2 standards that will require noranl operacions within the uraniv fuel cycle to be cunducted in such a anner as to provide reasonable assurance that: (a) the annual dose equivalent does not exceed 25 nflliren to the whole body, 75 nillrens to the thyroid, and 25 allirems to any other organ of any member of the public; (b) the quantity of ${ }^{129}$ I released to the environnent per gigawatt-year of porver produced by the entire fuel cycle does not exceed 5 aillicuries.

A Light-Water Reactor (LWR) fuel repriscessing plant, such as that of Allied-General tuclear Services at Barmeil, South Carolina, ${ }^{3}$ annually will process fuel that contained 1500 metric tons of heavy netal (mHM = uraniu + plutonium) as charged to reactors which produce $242,000 \mathrm{mu}(\mathrm{e})$-year of energy during 1 year of operation. This 150s MITH will contain wore than $50 \mathrm{Cl}$ ${ }^{129}$ I (>300 kg) and, when processing 18 perforned 160 days after discharge of fuel from the reactors, wore than $1000 \mathrm{ci}^{131} \mathrm{I}$ (>10 $\mathrm{ag}$ ). This spent fuel will pass through ${ }^{4}$ process operations involving fuel dissolution, solvent extraction, sorption in solutions [such as $\mathrm{Bg}(\mathrm{Mr}-)_{2}-\mathrm{HWO}_{3}$ ], and sorption on sflver-exchanged zeolites and on lon exchange resins. These and other unit operations, such as neutralization of solutions and dist112tisa, are parts of an extrenely complicated systen of lodine transport to "a fer" final storage etations.

A quantitative description of the movesent of lodine in a fuel reprocessing plant on the basis of laboratory experivental data does not appear to be possible at the present time since any of the plant processes have not been studied in sufficient detall. For example, the kinetics of lodine corption In $\mathrm{Bg}\left(\mathrm{MO}_{3}\right)_{2}-\mathrm{HWO}_{3}$ solution or on silver-exchanged zeolites can not be determined on the basis of existing data. In the absence of 
laboratory data, descriptions of the chenistry and kinetics of a nuber of the processes involving lodine retention any not be possible unless appropriate data are obtained at the fuel reprocessins plant itself.

A nuclear fuel reprocessing plant, such as that at Barmell, Is designed to operate, and probably vill operate, without the aintenance of coastant flows of aterials from one equipment unit to another. Because of expected discontinuities in such flows, athentical calculations concerning the novenent of lodine through an actual plant could become extrenely cowolicated. The tine scales of flow discontinutities are not known but ay be in the range of a feu days to a few weeks. Howrever, much can be learned about the kinetics of any chentcal or physical processes from a nodel that assunes sone type of constancy or regularity of these flows.

The present report is concerned with a sodel of the time-dependent flow of lodine, stable and radloactive, through a fuel ieprocessing plant. This plant was first described by Finney et al, 4 in a generic cost/benefit analysis of the environmental inpacts of reprocessing LWR fuel; it is sinilar to, but somewhat more complicated than, the Barmell plant. The mathenatical codel of the conceprual plant is based on particular, potentially realistic assuaptions of continuous flow of lodine from one unit to the next; on the radioactive decay of a short-lived isotope; on physfcal and chenical retention of lodine in various process units; and on the discharge of part of the lodine into the envircment. Transfer of lodine and decay of ${ }^{131} \mathrm{I}$ In the conceptual plant under steady state conditions were described by Davis et al. ${ }^{5}$ in a generic cost/benefit analysis of the environmental Impact of reprocessing High-Temperature Gas-Cooled Reactor (HTCR) fuel.

Two of the prisery purposes of this report are to identify most of the variables that control the flow of lodine and to identify some of the various types of laboratory dats, such as kinetic rate constants and equipment holdup times, that could simplify the description of lodine flow in the reprocessing plant. By Identifying these data, the extent to wich such a plant must serve as an experimental unit could be reduced. 
It should be noted that. Iodine is shown to be dischnrged to the env.'rounent in two etreas, Q150E and Q160R. These, and the-correspondins environental sinks, unts 17 and 18 , are retained as separate itess in the atbentical analysis to differentiate between lodine that is discharged in the conventional off-gas strean (Q160E) and lodine discharged wth stea (Q150E). The nodel plant Is assuned to discharge excess water as sten carring volatile components such as lodine, but nct as liquid water, which would contain many radlonctive nuclides at low concentrations.

Flows of total lodine or ${ }^{131}$ I are expresed in PIg. 1 by the letcer Q followed by four alphameric characters. The first two characters specify the unit fron which lodine flows; the second two characters specify the unit to which lodine flows. Bach flow varlable has two possibie subscripts; subscript 1 refers to total lodine, and subscript 2 refers to the short-half-1ived fsotope ${ }^{131}$ I. For example, Q0001(1) = the rate of flow of total fodine from fuel storage to the grapłite burner or voloxidizer;

Q0103(2) = the rate of flow of ${ }^{131} I$ from unit? to unit 3 ;

Q1011(1) = the rate of flow of total lodine from unit 10 to unit 11;

Q160E(1) = the rate of flow of total lodine from unit 16 to the environent.

Equations that describe the flow of total lodine or ${ }^{131}$ I In the fuel reprocessing plant are expressed as a function of flows into and out of individual units as follows:

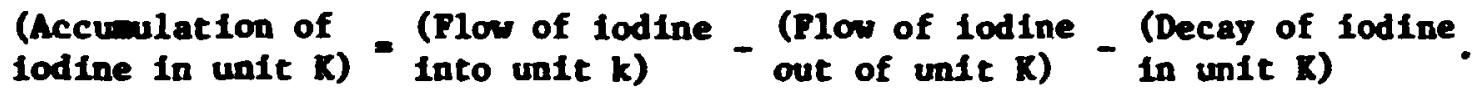

For example,

$$
\dot{H}_{1}=00001(1)-[Q 0102(1)+Q 0103(1)]-\lambda n_{1}
$$

and

$$
\dot{n}_{1}=Q 0001(2)-[Q 0102(2)+Q 0103(2)]-\lambda n_{1},
$$

where $\dot{H}_{1}$ and $\dot{n}_{1}$ represent the rates of accumulation of total lodine and of 131, sopectively, fin unit 1. The flow terms Q0001(1), Q0001(2), etc., are described above, while the term $\lambda n_{1}$ corresponds to the decay of ${ }^{131} I$ 
In unit 1. Due to its lons balf-life, ${ }^{129} \mathrm{I}$ is stable in the context of this report since the longest real tive of sigatificance is the lifetine (30 to 40 years) of the fuel reprocessing plant.

Terminoloss of equations such as $(B-1)$ and $(B-2)$, and their counterparts for each unit of equipent of Fig. 1, has been codified in this report to be suggestive of ponmen prograding. This perntes a close Identification with the computer prograns that are used to solve the mathematical oodel for the desired quantities. Calculation of these quanticies is based on numerical integration of two sets of 19 differential equations, each set involving 27 flows, one radianctive-decay constant, and 15 physical or chentcal rate processes. The total-iodine inventory and its rate of accumation in unit $K$ (Fig. 1 ) are sybolized by $E(K, 1)$ and $\operatorname{DER}(K, 1)$, respectively, instead of the $\mu_{k}$ and $\dot{H}_{k}$, which would correspond (with $k=1$ ) to $\mathrm{Eq}$. $(B-1)$. The ${ }^{131} I$ inventory and its rate of accumation in unit $K$ are symbolized by $\operatorname{Er}(K, 2)$ and $\operatorname{DER}(K, 2)$, respectively, instead of $n_{k}$ and $\dot{n}_{k}$, which would correspond to Eq. (B-2). Analytical descriptions of tine derivatives (DER) of inventories of lodine in the various units, with $\mathrm{L}=1,2$, are given by Eqs. (1) to (19).

$$
\begin{aligned}
& \operatorname{DER}(1, L)=[Q 0001(L)-T(1)]-[Q 0102(L)+Q 0103(L)] \text {. } \\
& \operatorname{UER}(2, L)=[Q 0102(L)+Q 0402(L)+Q 0502(L)+Q 1202(L) \\
& +Q 1402(\mathrm{~L})-\mathrm{T}(2)]-[Q 0209(\mathrm{~L})+Q 0216(\mathrm{~L})] \text {, } \\
& \operatorname{DER}(3, L)=[Q 0103(L)+Q 1303(L)-T(3)]-[Q 0304(L)+Q 0305(L)] \text {, } \\
& \operatorname{DER}(4, L)=[Q 0304(L)-T(4)]-[Q 0402(L)+Q 0409(L)] \text {, } \\
& \operatorname{DER}(5, \mathrm{~L})=[Q 0305(\mathrm{~L})-\mathrm{T}(\mathrm{S})]-[Q 0502(\mathrm{~L})+Q 0506(\mathrm{~L})+Q 0507(\mathrm{~L})] \text {, } \\
& \operatorname{DER}(6, L)=Q 0506(L)-T(6) \text {, } \\
& \operatorname{DER}(7, L)=[Q 0507(L)-T(7)]-[Q 0713(L)+Q 0714(L)] \text {, } \\
& \operatorname{DER}(8, L)=[Q 1008(L)+Q 1308(L)-T(8)]-[Q 0810(L)+Q 0815(L)] \text {, } \\
& \operatorname{DER}(9, L)=[Q 0209(L)+Q 0409(L)-T(9)]-[Q 0910(L)+Q 0919(L)] \text {, } \\
& \operatorname{DER}(10, L)=[Q 0810(L)+Q 0910(L)-T(10)]-[Q 1008(L)+Q 1011(L)] \text {, } \\
& \operatorname{DER}(11, L)=[Q 1011(L)-T(11)]-Q 1112(L) \text {. }
\end{aligned}
$$




$$
\begin{aligned}
& \operatorname{Dxa}(12, \mathrm{~L})=[\mathrm{Q1112}(\mathrm{L})-\mathrm{T}(12)]-\mathrm{Q1202}(\mathrm{L}) \\
& \operatorname{DER}(13, \mathrm{~L})=[\mathrm{Q} 0713(\mathrm{~L})-\mathrm{T}(13)]-[Q 1303(\mathrm{~L})+01308(\mathrm{~L})] \text {, } \\
& \operatorname{DER}(14, L)=[Q 0714(L)-T(14)]-Q 1402(L) \text {, } \\
& \operatorname{DER}(15, \mathrm{~L})=[\mathrm{Q} 0815(\mathrm{~L})-\mathrm{T}(15)]-Q 150 E(\mathrm{~L}) \text {. } \\
& \operatorname{DER}(16, L)=[Q 0216(L)-\mathrm{T}(16)]-Q 160 E(L) \text {. } \\
& \operatorname{DEA}(17, \mathrm{~L})=Q 150 E(\mathrm{~L})-\mathrm{T}(17) \text {, } \\
& \operatorname{DER}(18, \mathrm{~L})=\mathrm{Q1602}(\mathrm{L})-\mathrm{T}(18), \text { and } \\
& \operatorname{DeR}(19, L)=\operatorname{cog} 19(L)-T(19)
\end{aligned}
$$

In these equations, $T(K)$ corresponds to $\lambda_{n_{k}}$ of $\mathrm{Eq}_{\mathrm{q}}(\mathrm{B}-2)$ and is defined as:

$$
T(R) \equiv E R E(K, 2)
$$

where

$E I$ = the radioactive decay constant, $\lambda$, of ${ }^{131}$ I $(0.0861 /$ day $)$, and $\operatorname{Ex}(R, 2)=$ the inventory of ${ }^{131} I$ in unit $R$.

The two sets of 19 differential equations, Eqs. (1) to (13), of the time-dependent wodel of icdine accumulation can be integxated when we specify the initial inventory in each unt, the initial value of each flow, and a nethod for evaluating the time dependence of these flows. In this report, we nave considered only a new plant in which all initial inventories are zero and all initial fluw rates are zero except those into unit $1, \dot{Q 0001}(1)$ and Q0001(2). The value of Q0001(1) is set equal to 1.0 (1.e., 1 day's input/day), and the value of $Q 0001(2)$ is set equal to 1.0D-7* in accord with previous discussions ${ }^{7}$ concerning the activicy of ${ }^{131}$ I in an LWR fuel reprocessing plant, wherein the fuel is processed 160 days after discharge from the reactor. The assueptions used to calculate the remaining two sets of 26 flows and the use of avallable experimental data are described in the next section.

The D refers to double precistion. Thus, 1.0D-7 means $1 . \times 10^{-7}$ in double-precision calculations. 


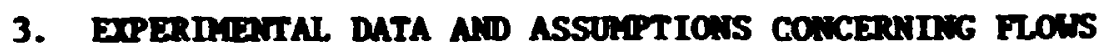

Host of the available experimental information pertaining to lodine flow in process units shosn in Fig. 1 are sumarized in Table 1 as DFs, as fractions (A13 or ASI and A52) of lodine flowing in one of two or three possible directions, as the ratio of flows $(A 1, A 3)$ in two possible directions, or as the fractional rate of recycle (due to sparging, purging, or venting) of lodine from storage tanks (RECYCL and BLVAT). The values of these varfables are not known very accurately; in addition, all values depend upon how a particular unit of process equipinent is operated. For exple, the vartable RECYCL will be as large as 0.00216 only if the sparge or purge rate at the ILU storage tank, Fig. 1 , is sufficiently 10 , so that lodine in liquid and vapor phases is in therwodynanic equilibriu and the equilibriun conditions correspond 5 to an lodine equilibrium concentration ratio $[\mathrm{C}(\mathrm{liq}) / \mathrm{C}$ (vap)] of 5000 .

Each pair of equations, (1) to (19), contains terns for lodine entering a unt and lodine leaving a unit; in the case of units 17 and 18, each the enviroment, and unft 19, containing permanently isolated lodine, only ${ }^{131}$ I leaves the unit, by decay. The codel of this report is based on the assumption that the rate at which lodine (total, stable, or radioactive) leaves a unit is proportional to the asount of iodine in the unit (wore specifically, the degree to which the unit is saturated wth fodine). This approach was used previously ${ }^{7}$ and 18 expressed as:

Total Flow of,$I_{2}$ out of unft $K=$ [Total Flow of $I_{2}$ into unit $K-T(K)$ ]

$$
\text { * EN }(R, 1) / \operatorname{EnMX}(\mathrm{K}) \text {. }
$$

Here,

$$
\operatorname{EMax}(K)=\text { the capacity of unit } K \text { for todine. }
$$

To maintain consistency with the definition of EN(K,1), EMMPX(K) is expressed in units of days of lodine input to the plant. For example, the graphite burner or voloxidizer unit 1 may have a capacity of a few hours of Input of lodine; that is, after a few hours of operation, lodine leaves unit 1 as fast as it enters the unit, except for radioactive decay. 
Table 1. Experimental information used in analyzing the reference fuel raprocaseing plant

Variable Definition and ralue

Q0001(1)

Set, for convenience, equal to 1.000 unite of lodine Input per day.

Q0001 (2)

Set equal to $1.0 \mathrm{D}-7$ times Q0001(1); that 18, the mase flow of "'I w111 be in the order of 1.0D-7 times the total-iodine flow.

Al

Th1s 1a the rat1o, Q0102(L)/Q0103(L), of lod1ne that vapor1zes in the head-end step (uritt 1 of $\mathrm{Fig}_{\mathrm{g}}$. 1) to that which remalns in the fuel particles. Vaporized lodine enters the off-gas ayatem (unit 2) while lodine remainine in the fuel flows to the dissolver (unit 3 ) and becoies part of tise more complex 11quid atream (unit 5, etc.).

- 0.0 for an LWR fuel reprocesaing plant not having a voloxidizer system.

$=0.6$ approximately, for a voloxidizer unit applicable to Liru sr.d LMFBR fuel reprocessing plants.

- 0.67 approximately, for the graphite burner system of an HIGR fuel reprocessing plant.

This 18 the DF of unit 2 [which might be $\mathrm{Hg}\left(\mathrm{NO}_{3}\right)_{2}-\mathrm{HNO}$, solution or othe:- or imary lod ine-removal unit] for a nonradioactive lojine species. It also 18 equal to $[Q 0209(\mathrm{~L})+Q 0216(\mathrm{~L})] / Q 0216(\mathrm{~L})$.

- 100. very conservatively, for $\mathrm{H}_{8}\left(\mathrm{NO}_{3}\right)_{2}-\mathrm{HNO}$, solutions.

- 1000. conservatively, for the Iodox process.

Th1 a ia the ratio [Q0304(L)/Q0305(L)], alm1lar to Al, of Iodine that vaporizes in the dissolver (unit 3 of Fig. 1) to tlit which remaine in the liquid. Vaporized lodine flows to unit 4 while unvaporized lodine flows to the solvent extraction system (unit 5 ) and remains in the liquid system. 
Table 1. (Continued)

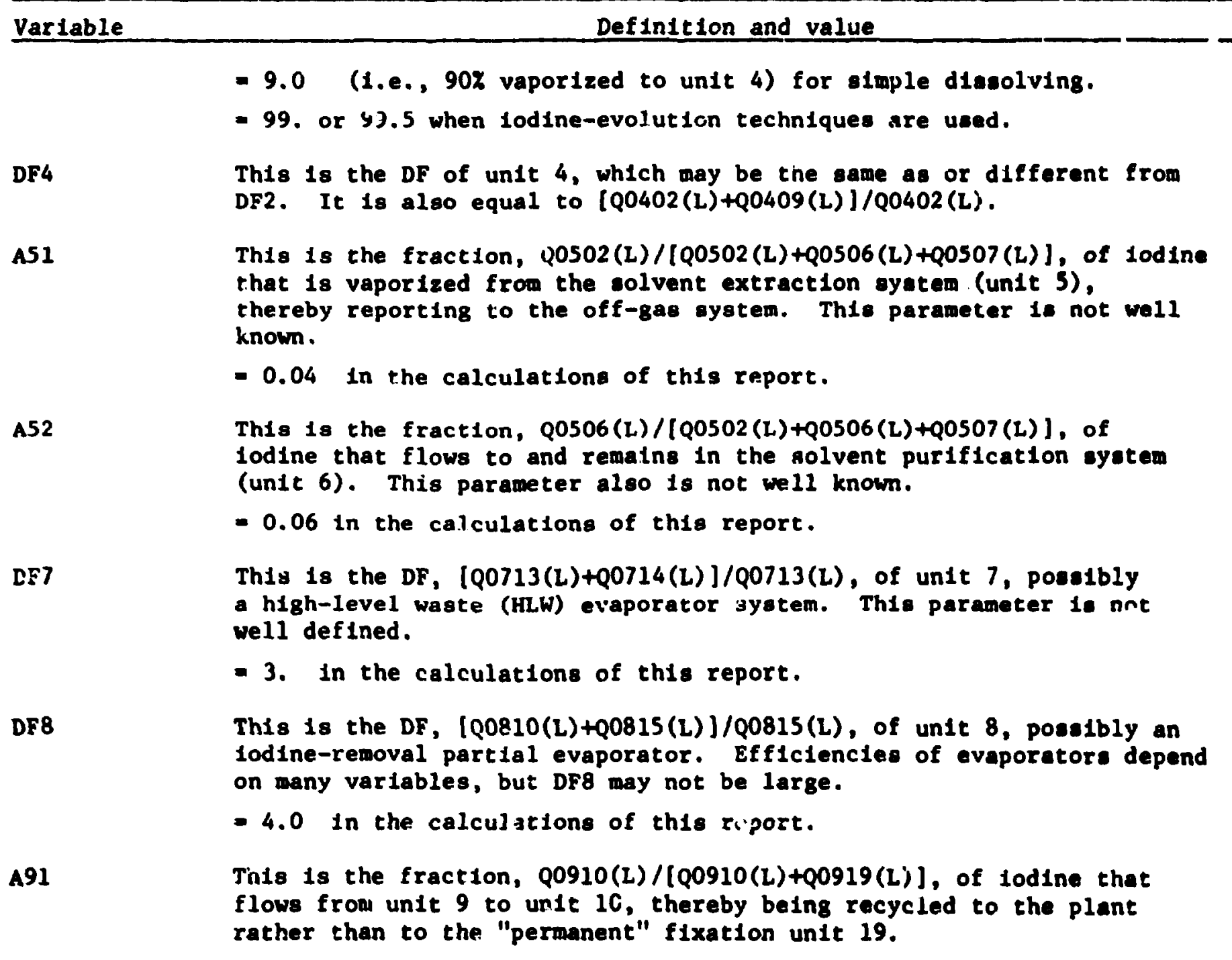

Reference

Th1s 18 the DF of unit 4, which may be the same as or different from

Th1s is the fraction, Q0502(L)/[Q0502(L)+Q0506(L)+Q0507(L)], of lodine that is vaporized from the solvent extraction ayatem (unit 5 ), known.

Th1s 1s the fraction, Q0506(L)/[Q0502(L)+Q0506(L)+Q0507(L)], of (unit 6). This parameter also is not well known.

rather than to the "permanent" fixation unit 19. 
Table 1. (Continued)

Varlable

Definition and value

Reference

- 1. If no fixation is performed.

- 0. If all lodine fron unit 9 goes to unit 19; but $A 91$ muat be greater than 0 . for purposes of computation.

DE10

Th1s 1s the DF, $[Q 1008(L)+Q 1011(L)] / Q 1008(L)$, of un1t 10 , the ILW evaporator. Th1s parameter may be very large, depend1itg on the dealgn and care of operation of the unit.

- 100. In the calculations of this report.

A13

This is the fraction, Q1303(L)/[Q1303(L)+Q1308(L)], of lodine leaving

unit 13, a nitric acid recovery oystem, that enters unit 3 .

- 0.0 If lodine 1s not rucycled t.c the disaolver ayutem.

- <1.0 If lodine 1s recycled, In recovered HNO,, to the discolver.

R(-RECYCL) Fractional rate of recycle of loding from the MLW storage tank.

$\leq 0.00216$.

Fractional rate of recycle of ludine from the HLW storage system. 
Equation (21) describes one of the assuptions that defines the wodel of this report. A second assuption is that lodine remeral in each equipment unit (units 6 and 17 through 19 excepted since they are infinite sinks) is described by the first-order kinetic Eq. (22):

$$
S(K)=1-\exp [-\Lambda(R) * T] \text {. }
$$

where

$$
\begin{aligned}
& S(R)=\operatorname{EN}(\pi, 1) / \operatorname{Eanx}(R) \text {, the fraction of the capacity cf unit } K \\
& \Lambda(K)=\text { the tive constant for lodine retention in unit } R\left(\text { day }^{-1}\right) \text {; and } \\
& T=t \text { ine (days of reprocessing plant operation under the tdeal }
\end{aligned}
$$

The assumption of first-order kinetics is made because of the absence of experimental data on rates of reaction of lodine in the various units of $\mathrm{Fig}_{\mathrm{g}}$. 1. It is recognized that this essumption is not accurate for all units, particularly the silver zeolite bed of unit 16 and the lon exchange bed of unit 15. Further discussion of reaction races is included in Sect. 5. However, regardless of how $S(R)$ is calculated, it is used to evaluate flows according to Eq. (21), as show in detall in Appendix $A$.

Equatioss (21) and (22) are written to apply to tolai lodine. However, an additiona! assumption concerning the nodel is that complete isotopic exchange cccurs in each of the 16 units $(1-5,7-16)$ of equipment of F18. 1 . As a result of this assumption, Eqs. (21) and (22) also apply to ${ }^{131} \mathrm{I}$. Such an assumption is nearly correct as it pertains to the flow of lodine species frow a fuel dissolver, the solvent extraction system, waste rtorage tanks, distillation units, $\mathrm{Hg}_{8}\left(\mathrm{HO}_{3}\right)_{2}-\mathrm{HNO}_{3}$ scrubbers (used in units 2 and 4 at Barmelj ${ }^{3}$ ), the Iodox system, 11 and some other possible components of a fuel reprocessing plant. Assumption of complete exchange of molecularlodine species also probably applies to the flow of ludine in and through sliver zeolite, as prevlously discussed; ${ }^{7}$ however, there is uncertainty concerning the degree of exchange of lodtue present in organic lodides. 
The quantities $\Lambda(x)$ are actually calculated from the equation: $\Lambda(x)=\ln 2 . / \operatorname{tanhx}(\mathrm{x})$.

where ISinx(R) is a measure of lodine-retention tine in unit $R$. Individual values and defintitions of TEahx(K) are given in Appendix B.

Two other specifications are used in the present nodel, manely, that lodine flow from both the $\mathrm{MW}$ and,$W$ storage systens, urits 11 and 14 of P18. 1, is controlled by reprocessing-plant operators independent1y of flows into these units. In both cases, the flow of lodine from the unit is assumed to be proportional to the inventory of lodine in the unf:. This corresponds to a purge if there is flow, or to zero if there is no purge.

Based on the definitions and specifications given above, the following sequence of operations leads to deternination of all flow rates.

1. Solve the five pairs $(L=1,2)$ of flrw equations, (24) to (28).

$$
\begin{aligned}
& Q 0103(L)=[00001(L)-T(I)] * S(I), \\
& Q 0102(L)=Q 0103(L) * A 1 \\
& Q 1112(L)=R * F M(11, L) \\
& Q 1202(L)=Q 1112(L) * S(12), \\
& Q 1402(L)=\operatorname{HLVRT} \text { and }
\end{aligned}
$$

2. Solve the system of 18 simultaneous equations, expressed in eatrix form in Eq. (29), by numerical wethods. 15 It should be noted that, For brevity, $S(K)$ and $T(K)$ are expressed $a s S R$ and $T R$, and the subscript (L) has been ontted from flow terns in this equarion. It should also be noted that $A 91$ occurs $a 81 / A 91$. To avold numerical difficulties, $A 91$ should always be set to a value greater than 0.0 , even if 311 the lodine reaching unit 918 permanently fixed. In this case, a value such as A9I = 1.0D-10 is effectively equivalent to $A 91=0.0$.

3. Solve the final three pairs of equations, (30) to (32). Q0919(L) $=$ Q0910(L)*(1-A91)/A91, 
ฐิ

8
8
8
8
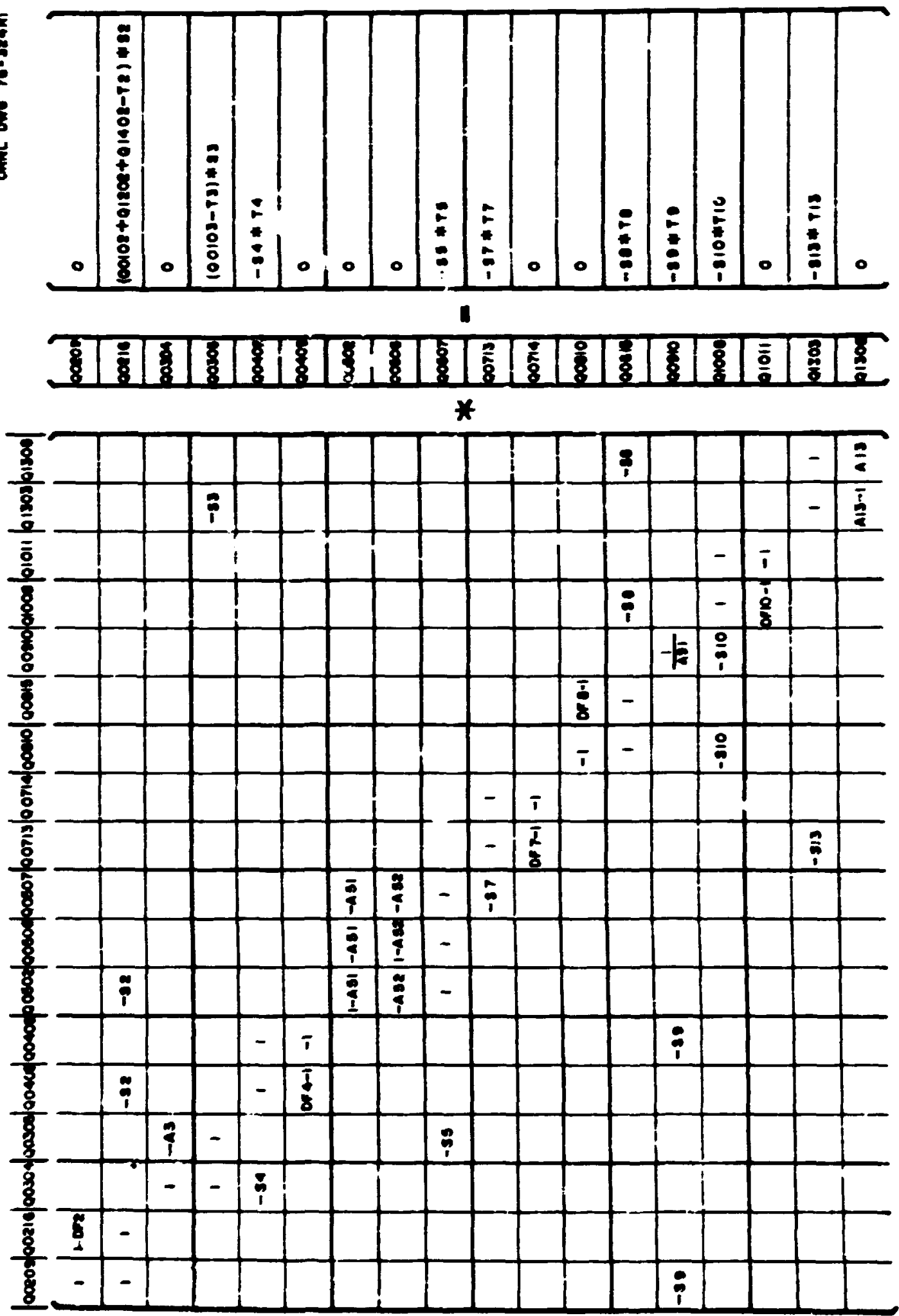


$$
\begin{aligned}
& \text { Q150E(L) }=[\text { Q0815(I.)-T(15)]*S(15), and } \\
& \text { Q160E(L) }=[\text { Q0216(L) }-\mathrm{T}(16)] * S(16) .
\end{aligned}
$$

Pollowing evaluation of flows according to Eqs. (24) through (32), the two sets of 19 differential equations, (1) to (19), con be integrated by nunerical ethods. 16

The entire process f evaluating thr two sets of 26 flows and then integrating the two sets of 19 differential equations by the nethods outlined above requires less than 0.1 sec per tine step with the In $360 / 91$ coputer. In the present studies, inftial time steps vere 0.02 days and were increased to 5 and 10 days after 100 days or wore of plant operation. Computer execution tive can be shortened $\sim 307$ on che IBM $360 / 91$ as described in Appendix C. However, programs listed in Appendix C are based on Steps 1, 2, and 3 (above).

\section{EXAYPLES OP CALCULATIONS}

Examples of calculated relative flow rates, of plant RFs, of untt $\mathrm{DPs}_{\text {, }}$ of relatfve radioactivities, and of total lodine inventories are shown in Figs. 2 to 12. The first five figures are for Case 1, which corresponds to Case $2 a$ of PInney et al. 4 and of Davis et al. 5 Case 1 of this report differs from Case 1 of refs. 4 and 5 by having an lodineresoval Ion exchanger (unit 15); In other aspects, it is the sane as Case 1 of these references. For example, only 907 of the contalned lodine 18 vaporized from the dissolver solution, and lodine fixation is not employed. Figures 2 and 3 contain plots of relative flows of lodine in sove of the liquid and gasborne streams during the first :,00 days of operatior: of a plant initially containing no lodine. As expected, the flows all Increase; sone of the flows attain constant values, corresponding to steady, state conditions and to saturation of various units with lodine, while others continue to increase. The curves in these figures are determined by the particular values of input parameters. Those values used to derive Figs. 2 to 6 are 11sted in Table 2 under Case 1. Two parametera, nowely Thaux(11) and TEMAX(14), in this table require further cownent 


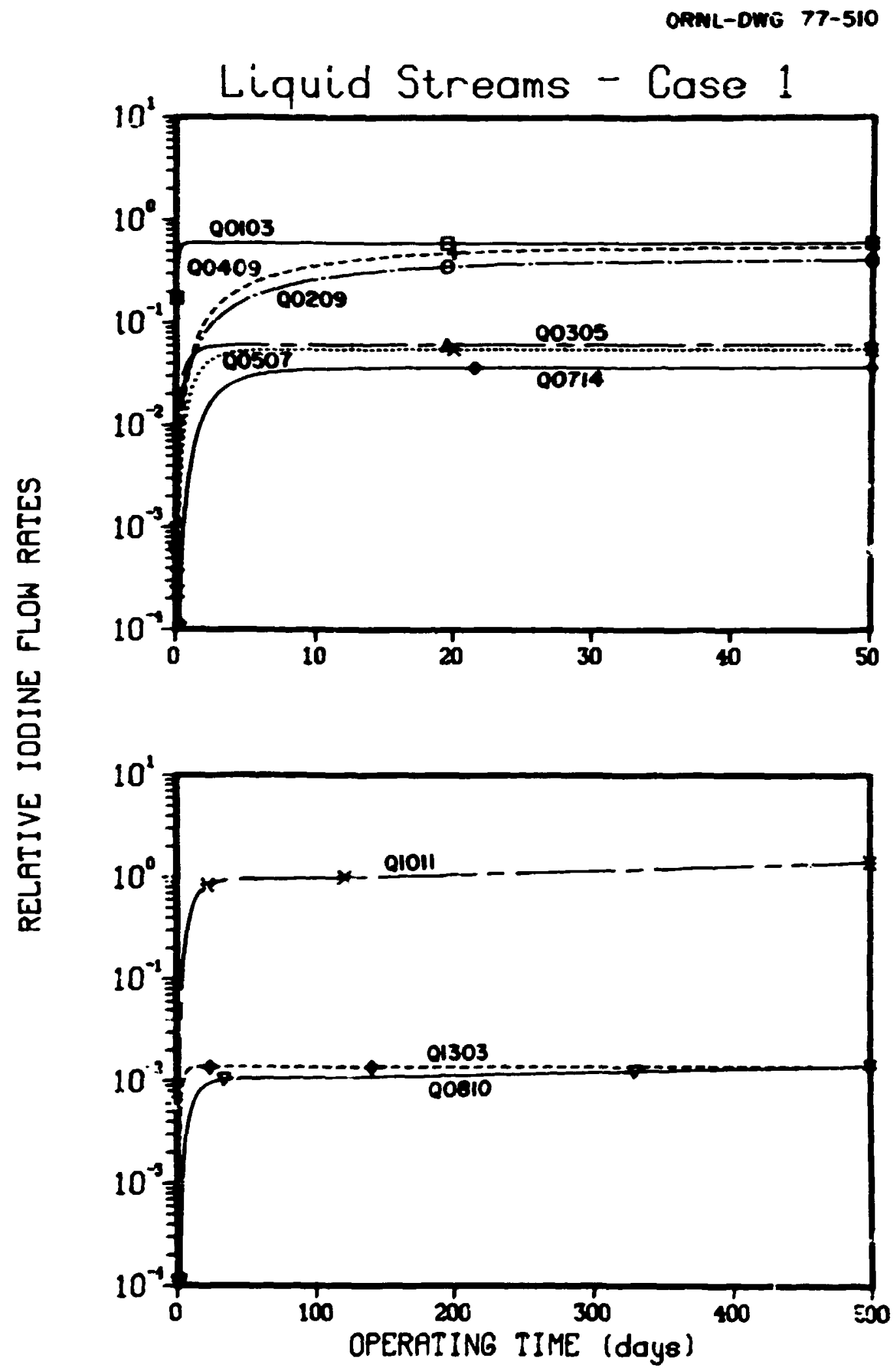
Case 1.

P1s. 2. Relative total-iodine flow rates in liquid st reans, 
ORNL-OWG 77-SI

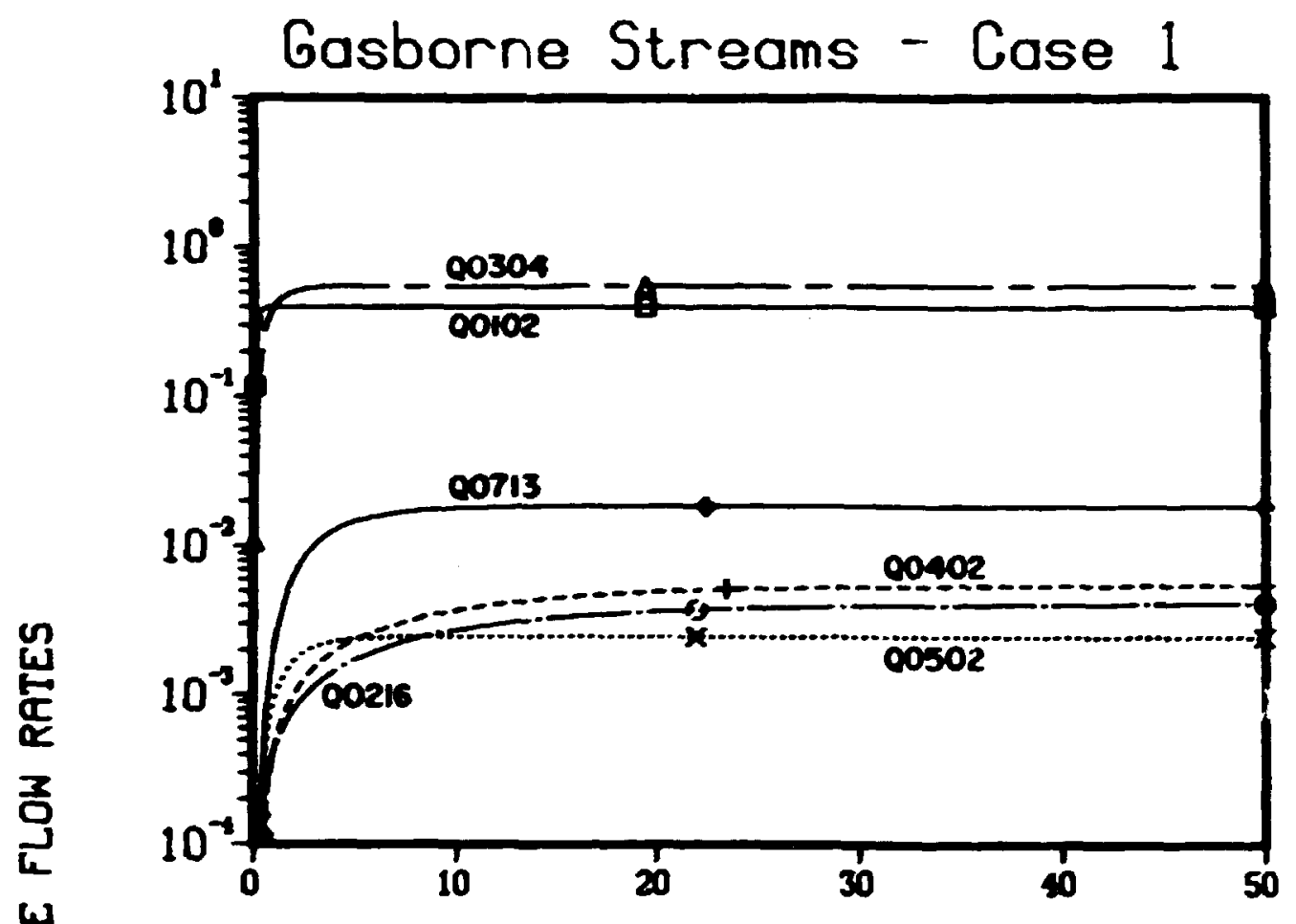

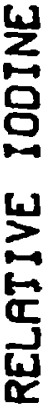

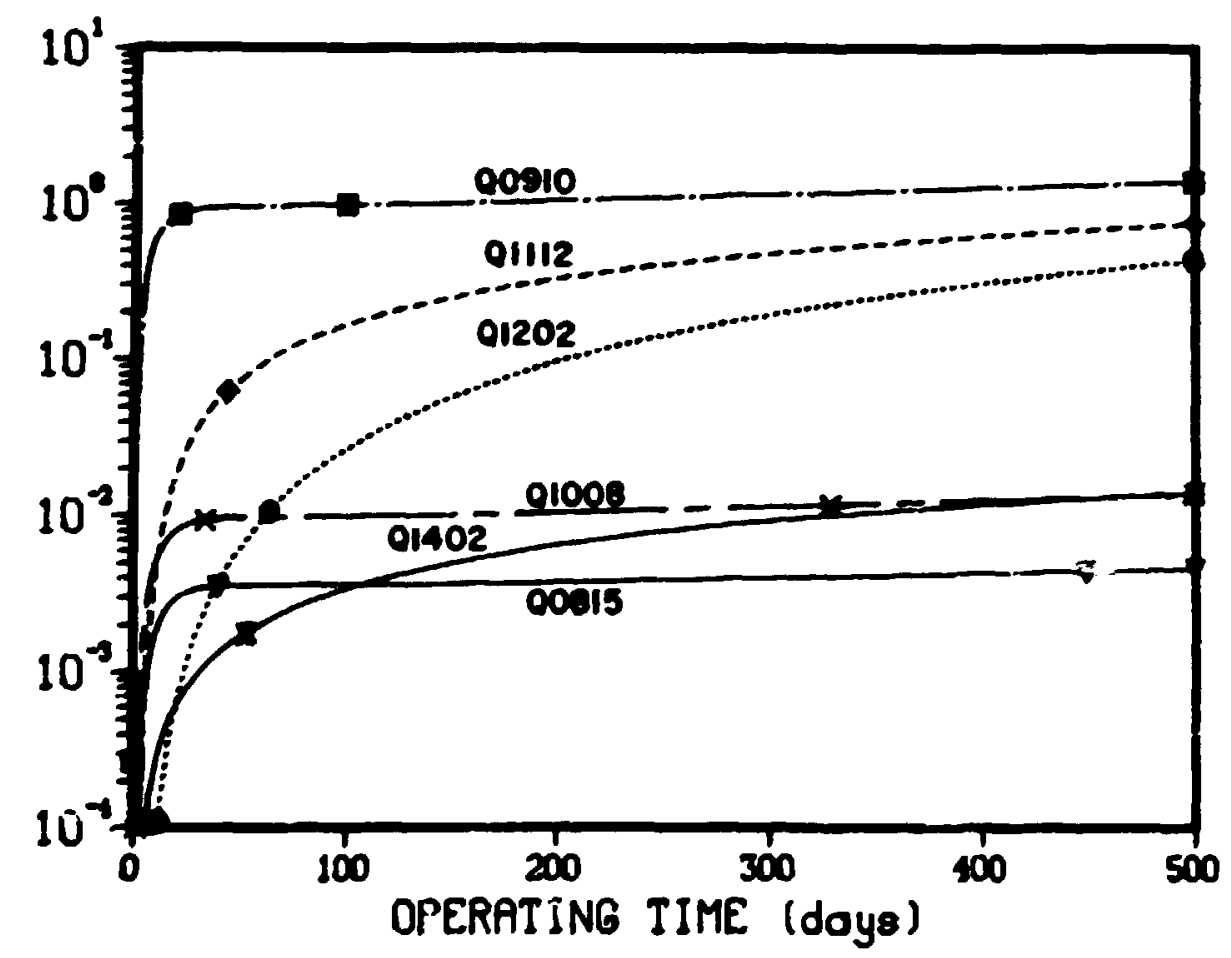
Cace 1.

P1g. 3. Relative total-iodine flow rates in gasborne streans, 


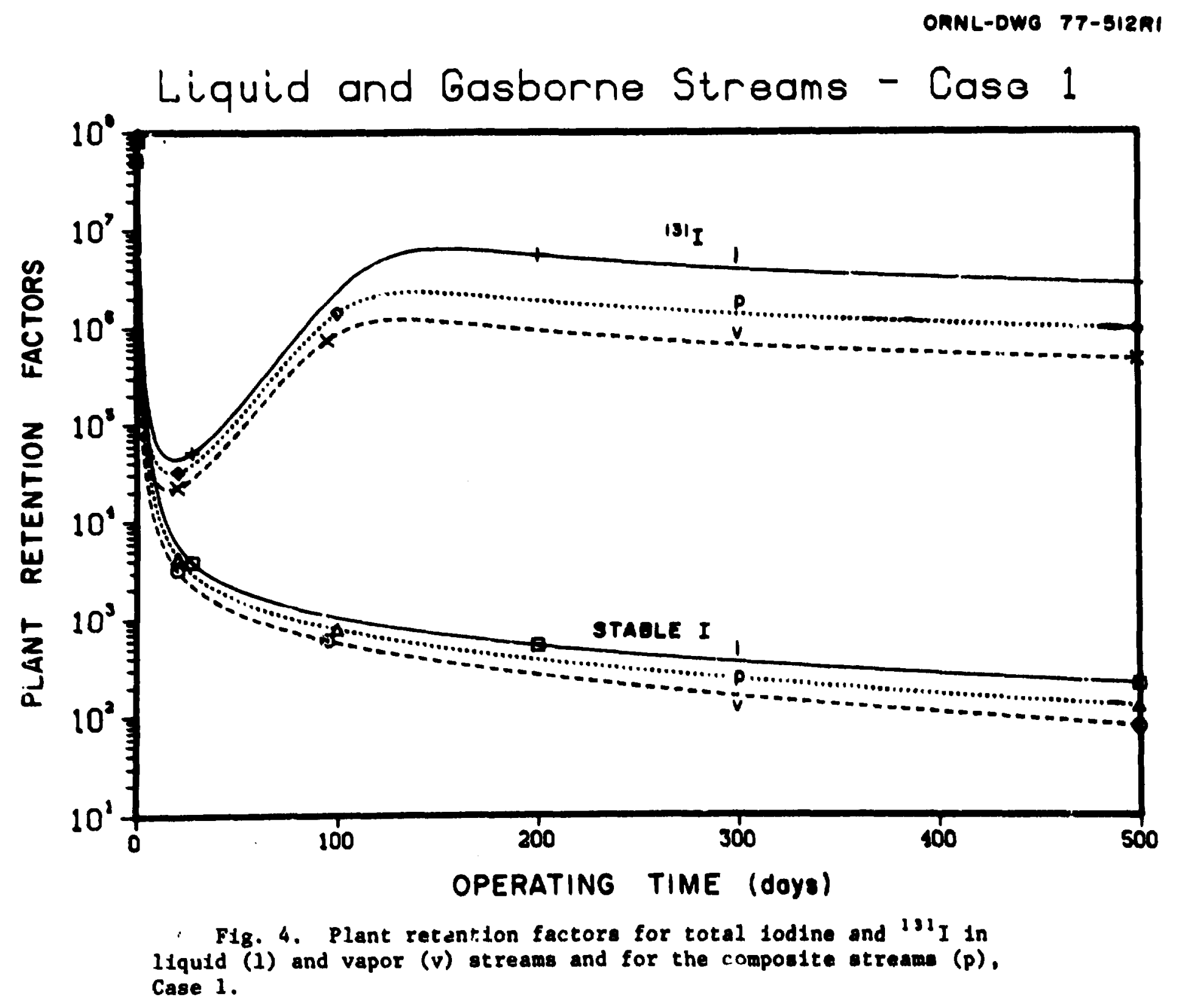




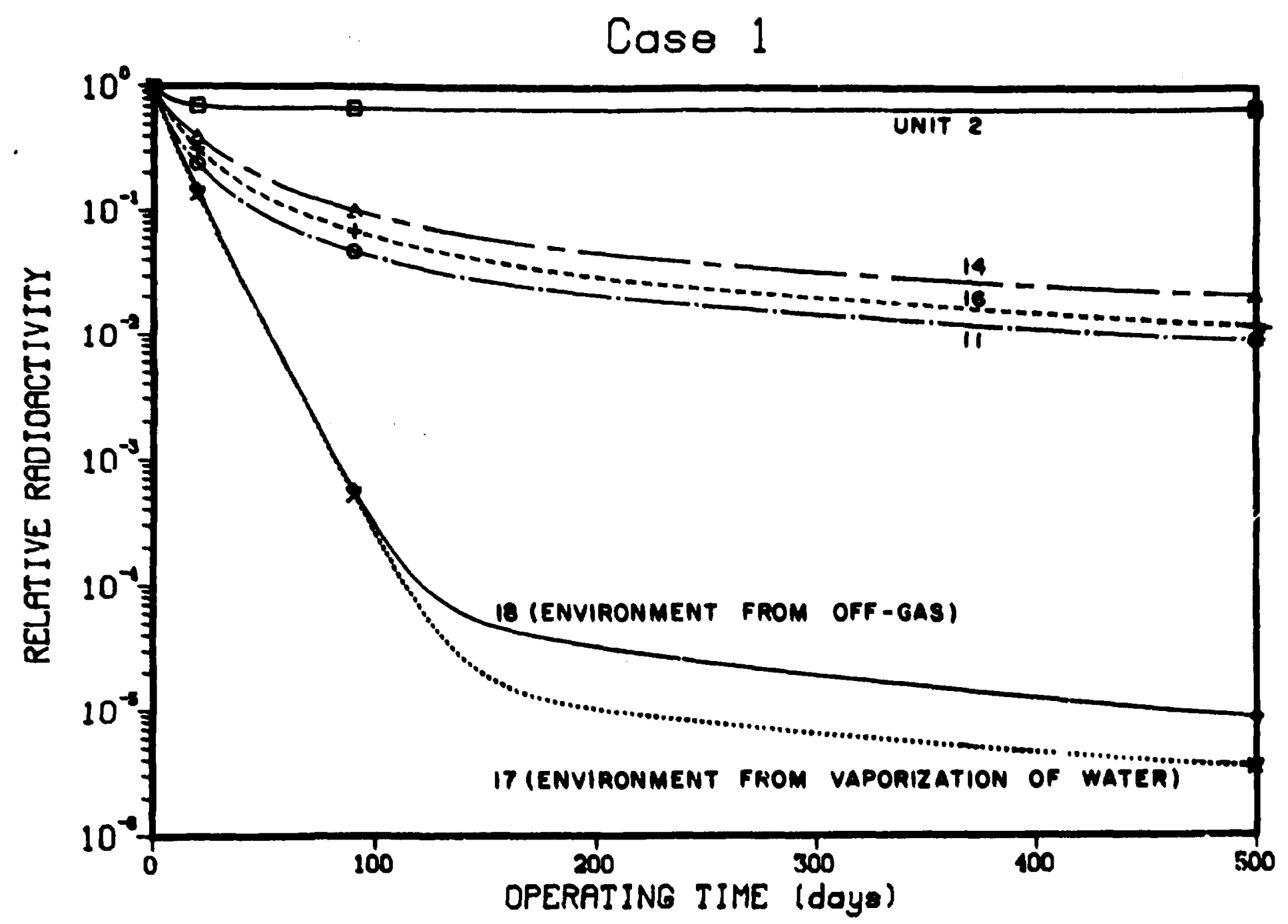

F18. 5. Relative radloactivity, due to "I'I, of lodine In some of the equipment units and in the environment, Case 1. 
OANL-DW6 77-514

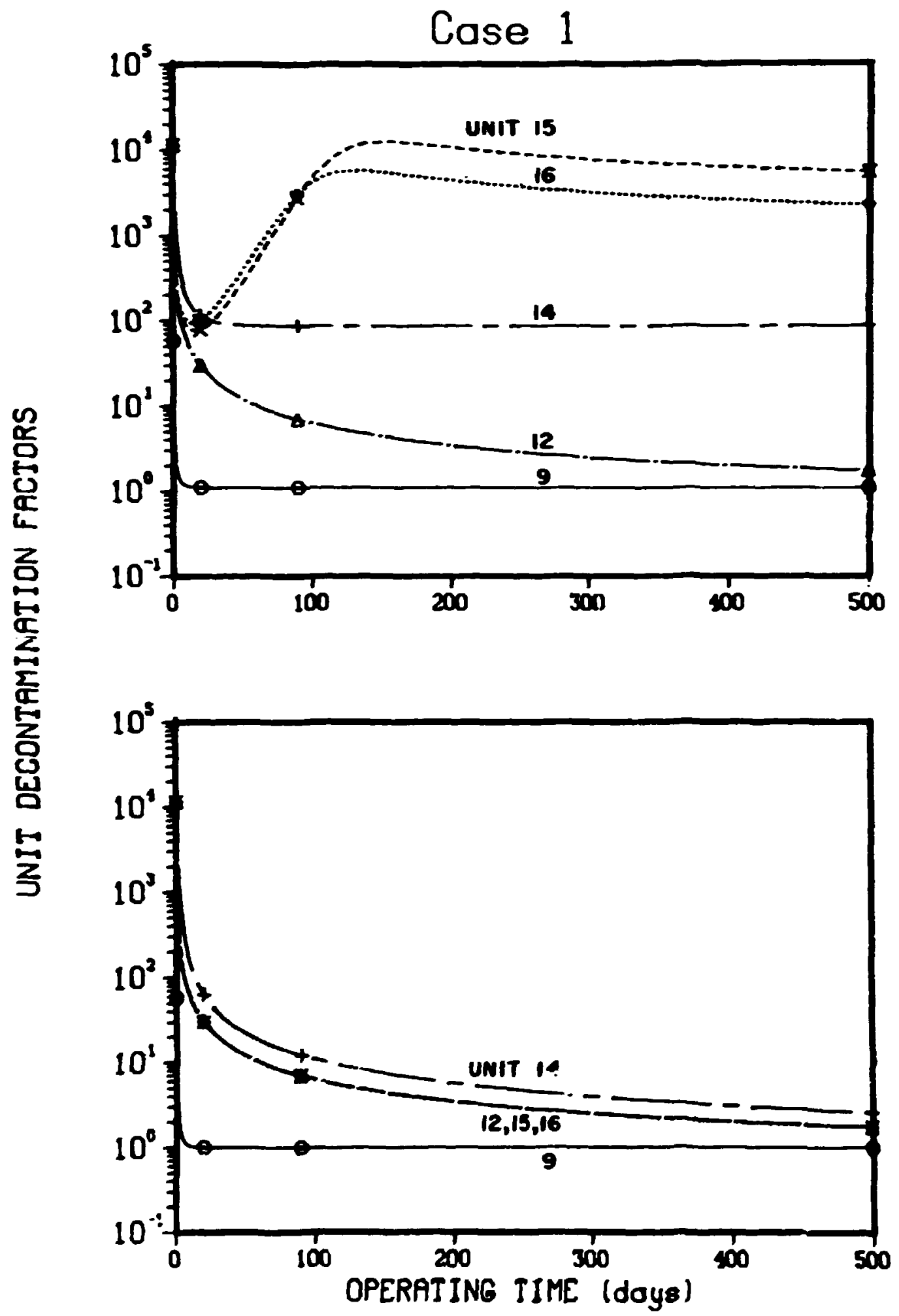

Fig. 6. Calculated time variation of decortanination factors of five process units, Case 1. 
ONNL-OWO P7-BIS

Case 2

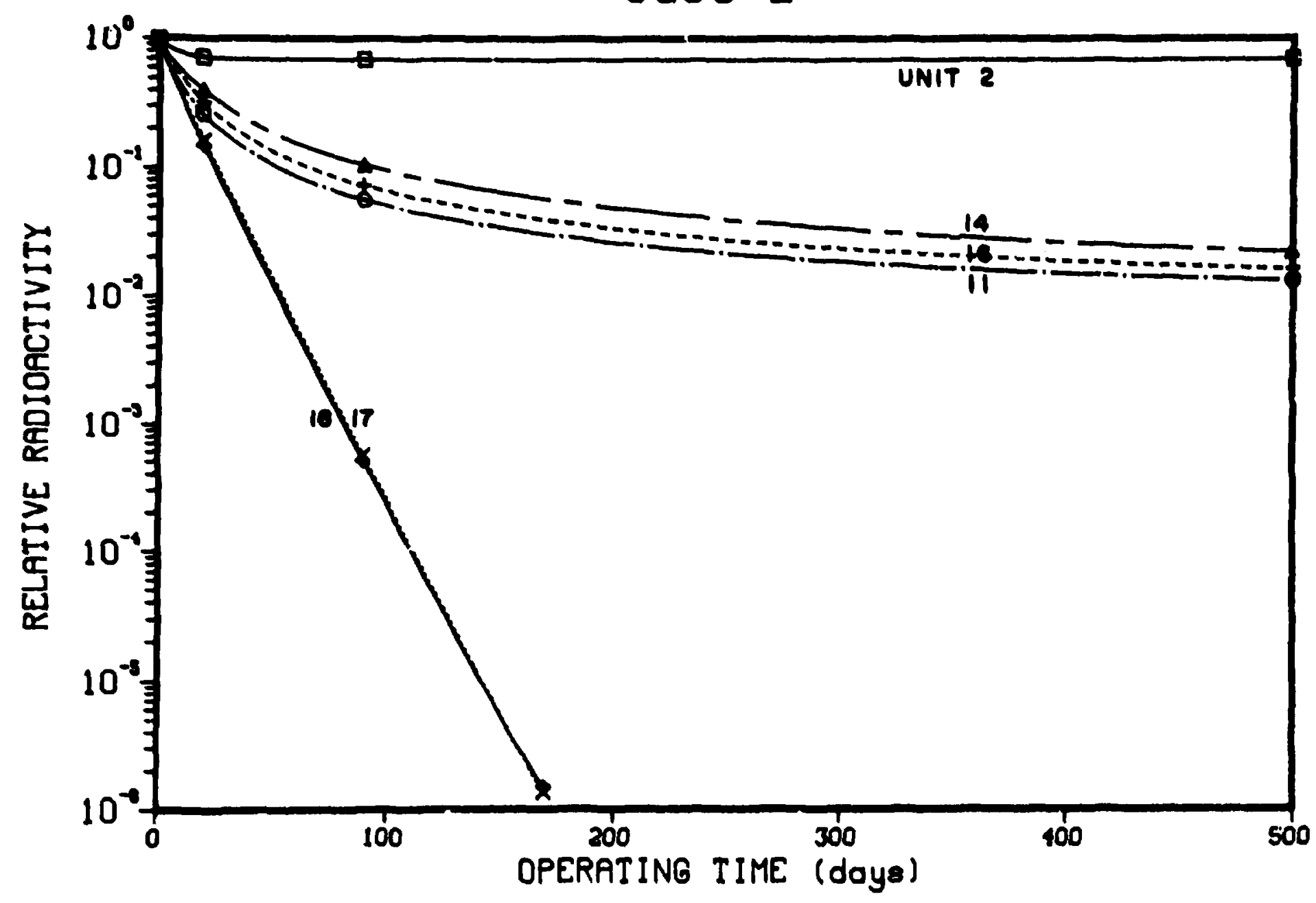

Fig. 7. Relative radloactivity, iun to '3'I, of lodine in some of the equipment unite and in the env: snment, Case 2. 


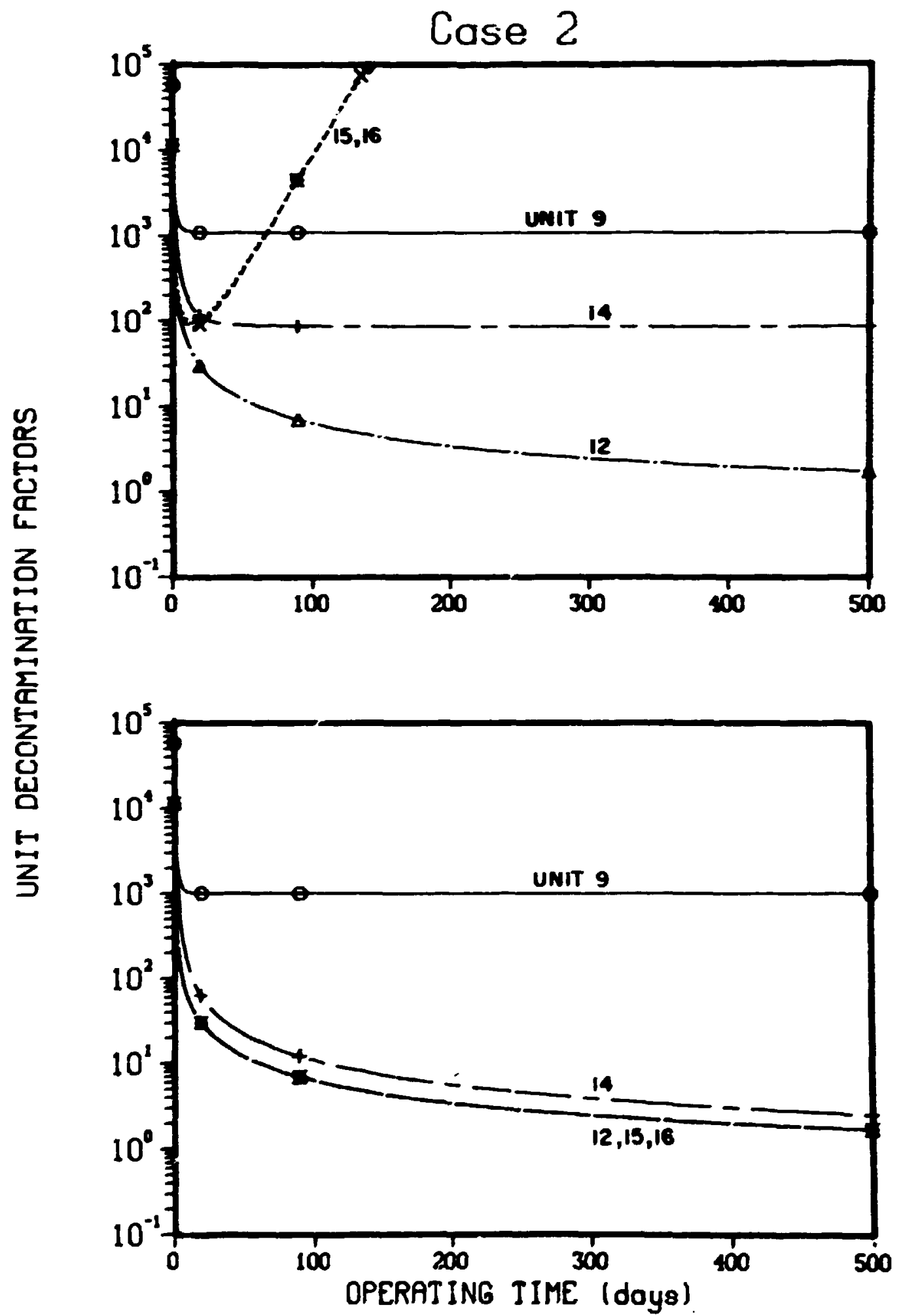

Fig. 8. Calculated time variation of decontamination factors of ftve process untts, Case 2. 


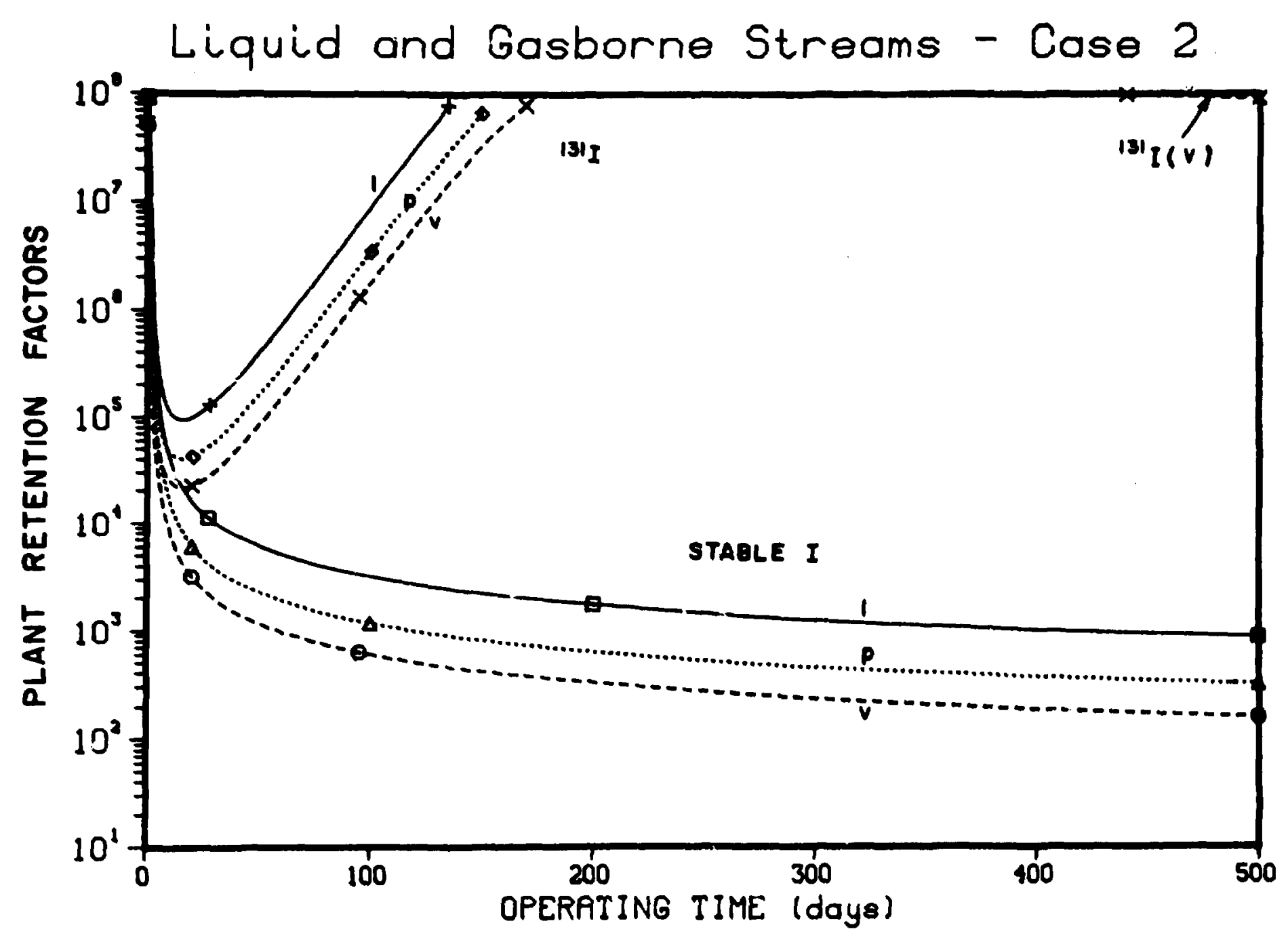

F1g. 9. Plant retention factorg for total lodine and ${ }^{19 l} I$ in liquid ( 1 ) and vapor (v) atreams and for the composite streams ( $p$ ), Case 2. 
ORNL-OWG 77-518

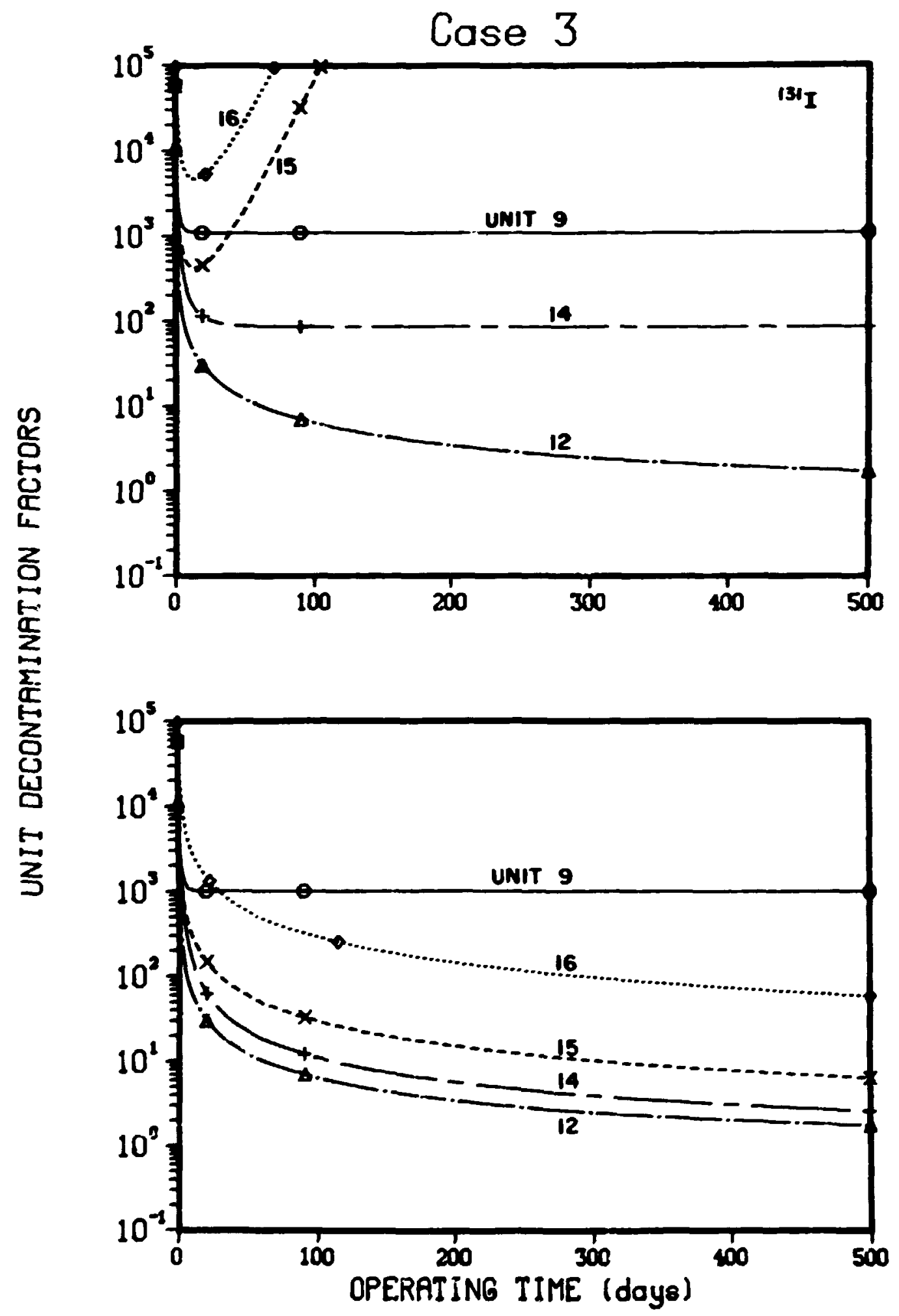

Fig. 10. Calculated time variation of decontamination factors of five process units, Case 3. 
ORNL-OWO 77-919

TOTAL IODINE INVENTORIES - Case 4

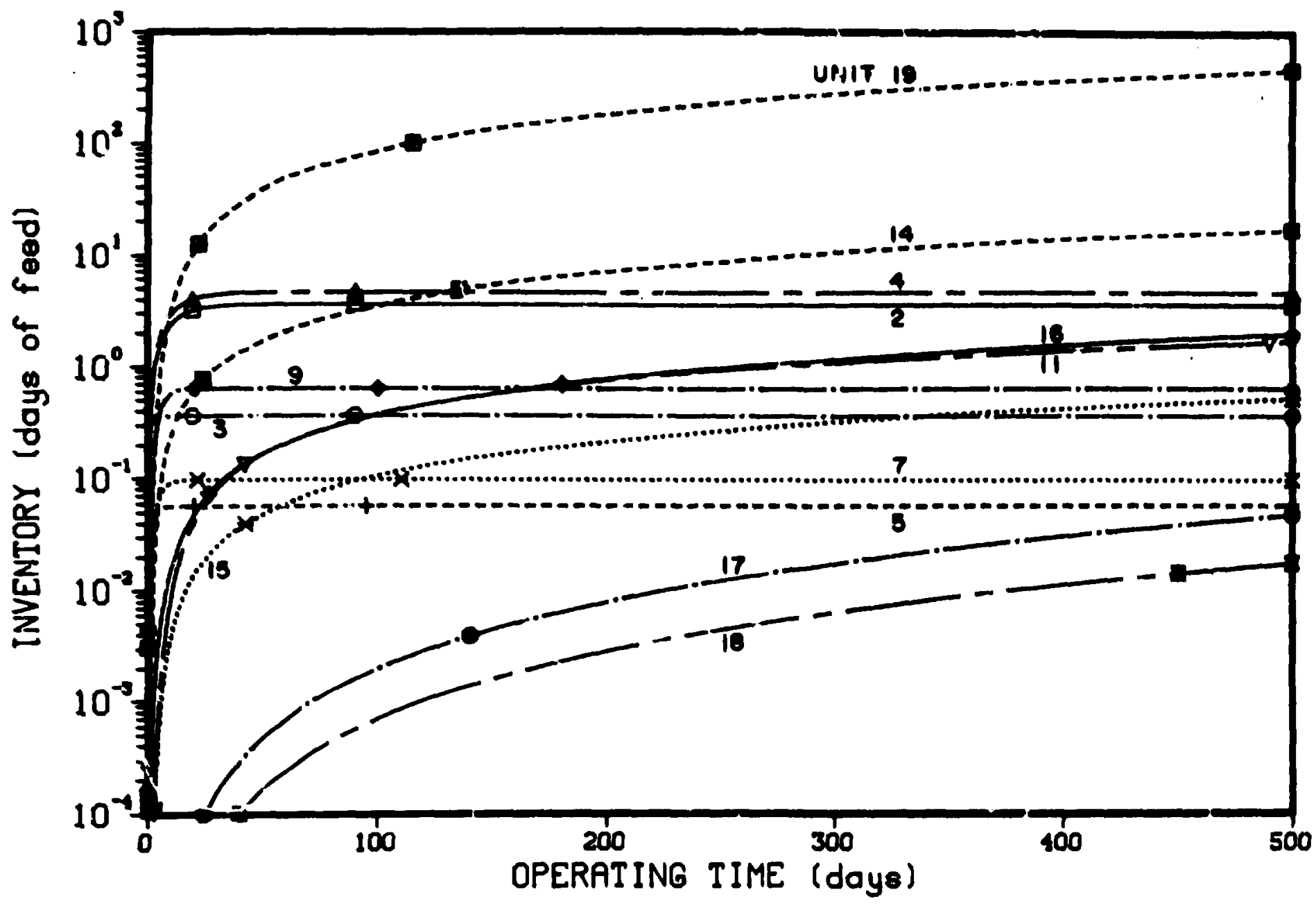

18. 11. Increase in Inventories of total lodine in plant equipment and In the environment (Uiits 17 and 18 of F18, 1), Case 4 . 
ORNL-DWG 77-520

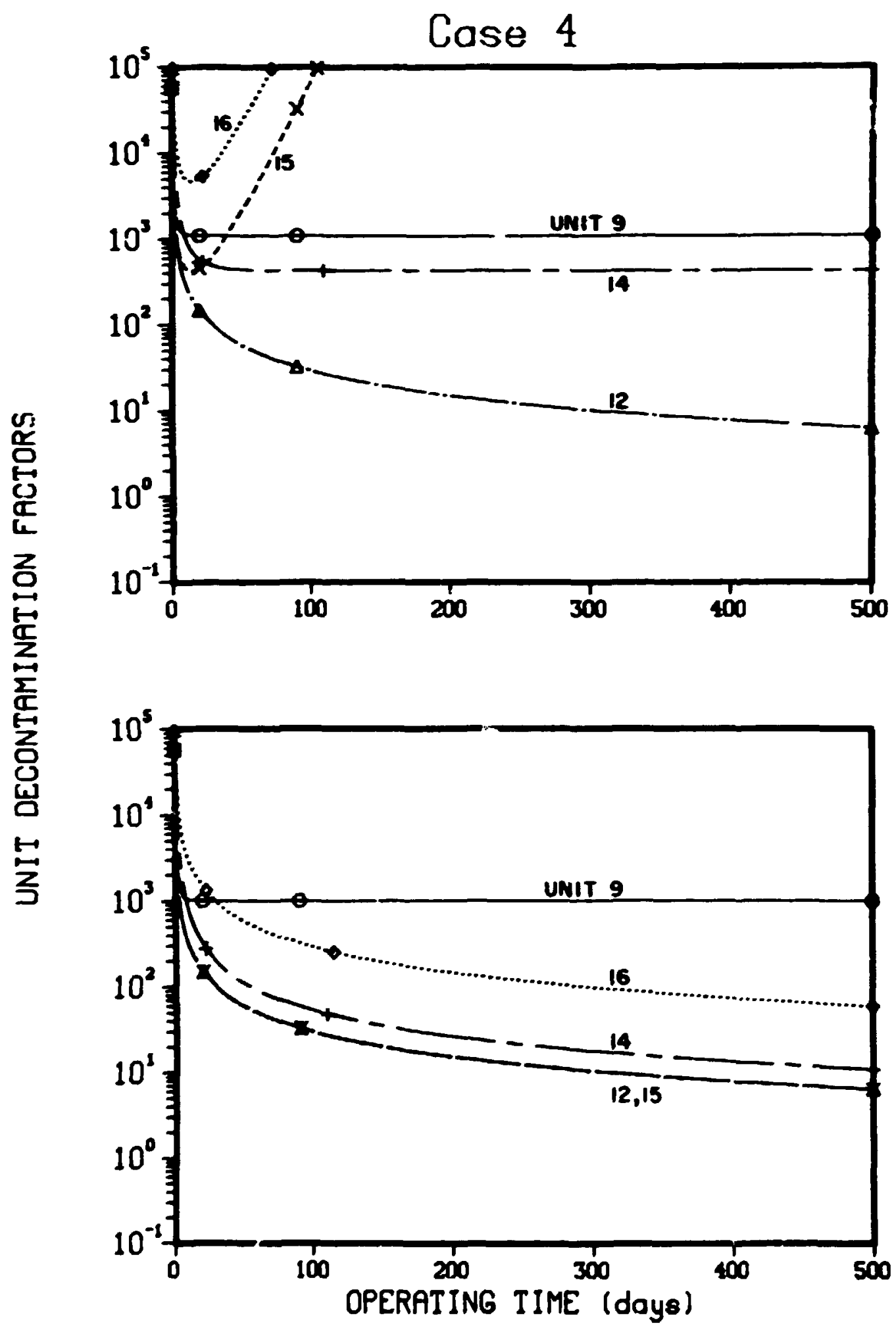

F18. 12. Calculated time variation of decontamination factors of five process untts, Case 4. 
Table 2. Values of paraneters used in sone case studies

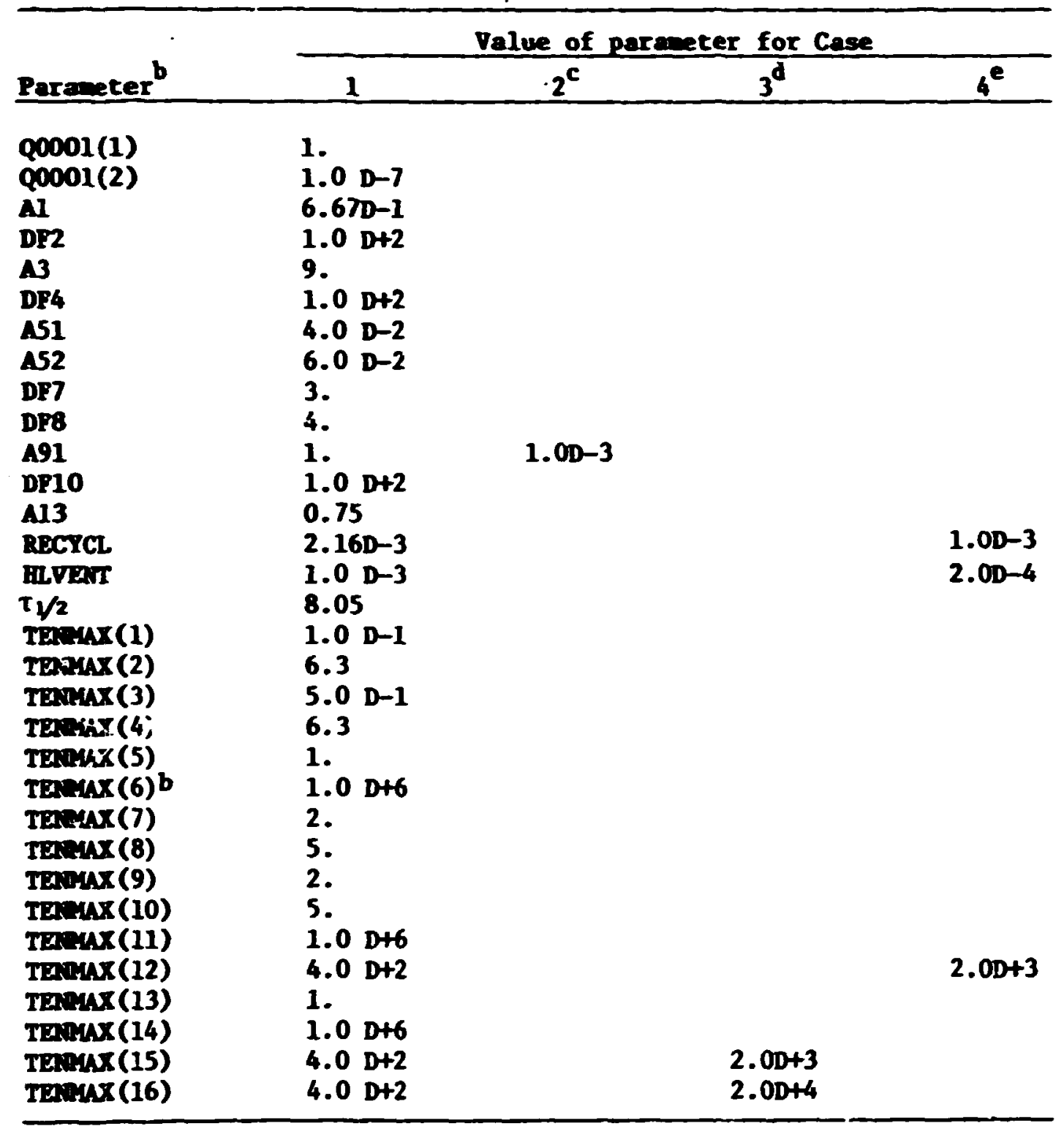

a Beyond Case 1, only changed paraneters are shown. Bach change applies to all subsequent case calculations.

breinx(6) is actually not used in the wodel since unit 6 (solvent purification) 18 assumed to be a permanent sink for todine.

Cas. ? corresponds to the discharge of 99.97 of the lodine collected in unit 9 to unit 19, where the lodine is permanently 1solated.

dCase 3 corresponds to increasing the capacities of units 15 and 16 unt11 their tise constants are 2000 days ( 5.5 years) and 20,000 days (55 years), respectivejy.

ease 4 correoponds to reducing rates of sparging HLW (unit 14) and IIN (unit 11) storage tanks and increasing capacity of unit 12. 
because of the very large value, $1.00+6$ days, assigned to then. By assigning large values to these parameters, It is appareat that the corresponding values $\Lambda(11)$ and $\Lambda(14)$ of Eq. (23) will be very anall and, therefore, that $S(11)$ and $S(14)$ of $\mathrm{Eq}$ - (22) will be nearly zero. Thus, a large value of Menux(K) betheatically cokresponds to a very large capacity of a uit for retaining lodine. or to the escape of very little lodine fron the unit. The units of interest bere are as follous: (1) the HW storage tank (unit 11), and (2) the Hu storage tank (unit 14). There is nothing unique about the assignment of $1.00+6$ days of lodine feed since any value greater than $21.0 \leq 44$ would adequately represent a very large lodtne storage capactity. If the value of ThMax(14) is in: the range of tens to hundreds of days, then unit 14 can be considered equivalent to a luW solidification systen frcm which all contained lodine is returned to the main process as flow Q1402.

Liquid and gasborne plant RFs for bot's total lodine and for ${ }^{131}$, shown in Figs. 4 and 9, are defined as:

$$
\begin{aligned}
& \text { Rate at which elenent or nuclide enters the plant in } \\
& \text { the designated streap } \\
& \text { Rate at which elenent or nuclide leaves the plant in } \\
& \text { the designated streal }
\end{aligned}
$$

Unit DFs show in Pigs. 6, 8, 10, and 12 are defined for total lodine and for ${ }^{131} \mathrm{I}$ as:

$$
D F=\frac{\text { Rate at which elesent or nuclide enters the unit }}{\text { Rate at which element or nuclide leaves the unit }} .
$$

Many aspects of Figs. 2 to 6, Case 1, require minimal discussion when the various curves are viewed in terms of Fig. 1. For example, steady state flow of lodine 18 achieved within 1 ess than 20 days of the start-up of a new plant in the following streass (as expected fron the input data of Table 2): Q0102 and p0103 from the graphite turner or voloxidizer; Q0305 from dissolver to solvent extraction system; Q0502, Q0506, and Q0507 from the solvent extraction syster; and Q0713 and Q0714 fron the HLU evaporator. However, steady state is not achieved for lodine flow from the MH evaporator to the MUH storage tank, Q1011, nor for lodine flows Q0209, Q0409, Q1122, Q1202, or Q1402. 
Plant RPs in P1g. 4 are defined as folluws:

$$
\begin{aligned}
& \operatorname{RP}(\ell)=Q 0103 / Q 150 E, \\
& R P(v)=00102 / Q 160 \mathrm{E},
\end{aligned}
$$

and

$$
R F(p)=(Q 0102+Q 0103) /(Q 150 E+Q 160 E) .
$$

The subseripts $l, v$, and p correspond to liquid strean, gasborne strean, and plant composite, respectively. Here, the subscripts 1 (for total Iodine) and 2 (for ${ }^{131} \mathrm{I}$ ) have not been includes in the flu teras for brevity. With these definitions and with nunerical examples, it is easy to show that the value of $\operatorname{RF}(p)$ is less than the large: value of either RF(l) and RF( $v)$ but greater than the smaller of these.

Figures 4, 6, 8 to 10 , and 12 show reversals of CPs and DFs for ${ }^{131}$ I that are readily explained. As described in ref. 7 , the DF for ${ }^{131}$ I exceeds that for stable lodine and ${ }^{129} \mathrm{I}$ by an amount that depends on the extent of isotopic exchange, the holdup tine during which radioactive decay can ocrur, the extent of lodine recycle, and the sorber operation time. In the present report, complete isotopic exchange has been asswed. The ratio $\operatorname{DP}\left({ }^{131} I\right) / D F$ (equipment), where DF (equifient) applies to stable ${ }^{127} \mathrm{I}$ or to long-lived ${ }^{129} \mathrm{I}$, is show for one set of conditions in Fig. 13 (taken from Fig. 6b of ref. 7). The paraneters of this two-unit systed are shown in $\mathrm{Fig}_{\mathrm{B}}$. 13. As can be seen, the ratio of DFs will be 1.0 only if the degree of isotopic exchange 1s 0.0 ; for all values of fractional 1sotopic exchange greater than 0.0 , there will be an Initial increase in the ratio $\mathrm{DF}\left({ }^{131} \mathrm{I}\right) / \mathrm{DF}$ iequipment), followed by a decrease. Por the paraseters used to obtain Fig. 13, the ratio ceases to increase after $\sim 100$ days. This figure is based on a constanc feed rate of ${ }^{131} I$ and stable lodine; the increase in the ratio of DFs corresponds to the Increase shown in Pigs. 4, 6, 8 to 10, and 12 starting after $\mathrm{w}_{10}$ days of operation of the model plant of this report.

The decrease in the RF or DF of ${ }^{131} I$ thet is show for the first 10 days in Figs. 4, 6, 8 to 10 , and 12 does not appear in Fig. 13 because of differences in initial flow conditions. Thus, Fig. 13 is based 


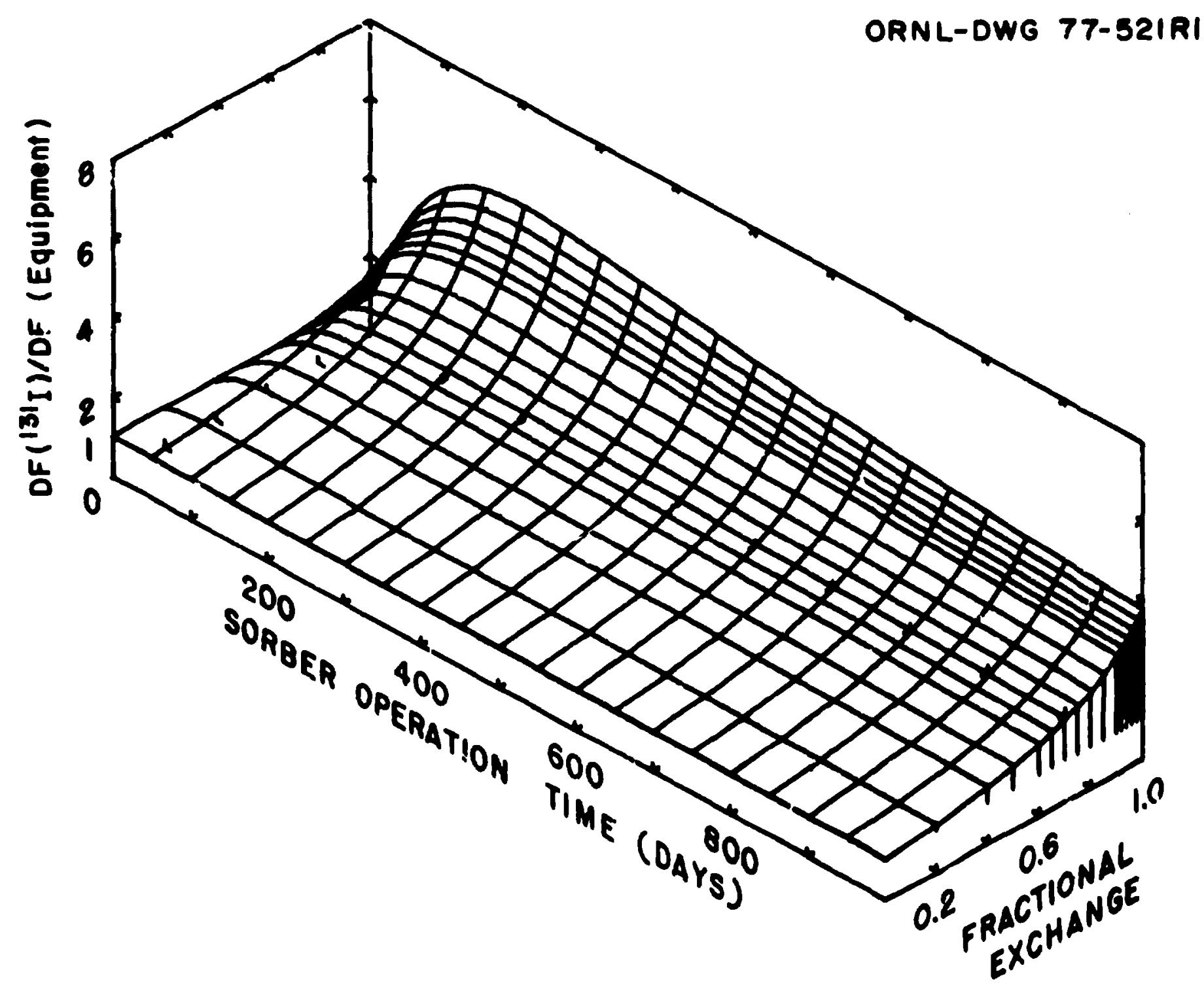

F1g. 13. Effects of time, resycle, and eractional exchange on relat Ive decontamination factors for 1I I. DF(oquipment) - 20 , TENMXX -60 daya, $R=\operatorname{RECYCL}-1 \times 10^{-3}$ (from ref. ?). 
on a constunt flow of ${ }^{19}{ }^{\prime} I$ and stable iodine into the syster; by contrast, the flars of radioactive and stable lodine into units 15 and 16 are Initially zero, but these flows increase rapidl. The flow of stable lodfine to unit 15, Q0815(1), parallels that of Q0810(1), and the flar of stable lodine to unic 16, Q0216(1), parallels that of Q0209(2) (Fig. 2). Fithentically, the first reversals in FIgs. 4, 6, 8 to 10, and 12 occur as a result of the differences:

[Q0815(2)-T(15)], From Eq. (A-28;,

and

[Q0216(2)-T(16)], fron Eq. $(A-2 ;)$.

Initially, the teres Q081S(2) and Q0216(2) of ${ }^{131}$ I flow into units 15 and 16 doaninate the terms $T(15)$ and $T(16)$, which are the decay rates $\lambda \mathrm{n}_{15}$ and $\lambda_{\mathrm{n}_{16}}$ of ${ }^{131} \mathrm{I}$ in these units. However, as a result of 1sotopic exchenge and long holdup tines, the terms $T(15)$ and $T(16)$ increase faster than the flow terms Q0815(2) and Q0216(2). These changes lead tc revereals in DFs for ${ }^{131} \mathrm{I}$.

The second reversals in the RFs and DFs of ${ }^{131}$ I are due to a reduction in the residual capacity (an approach to saturation) of units 15 ant 16. In an actual plant, these units vould be replaced or they aght Intially be considerably larger than those corresponding to case 1 of th'; report (F1gs, 4 and 6). Such an increase is shown in Cases 3 and 4 (Pigs. 10 and 12) wherein the variables Tuinx(15) and THMMX:6) vere increefici to 2000 days ( 5.5 years) and 20,600 days (55 years), respectively. This value for Twinx(16) Implies that the silver-exchanged zeoli'e unit 16 would not need to be replaced during the 30- to 40-year life of the fuel reprocessing plant.

The pernanent removal of 99.97 of the fodine reaching unit 9 by discharge from lists 2 and 4 through fixation in unit 19 produces a significant increase in plant CFs, as shom by a conparison of Pigs. 4 and 9. However, there are other important factors, such as the rates of purging or sparging units 11 and 14. These rates are reduced in Case 4. 
For the purpose of modelling the time-dependent flar of lodine through a particular nuclear fuel reprocessing plant, it would be wore efficient to include only those equipent units actually contained in the plant. For exmple, the Bardurell plant does not contain units 1,8, and 15 of F18. 1; bence, elinization of the equaticas for these units would siplify the compter calculations. Horever, some equipment units In Fig. I can be "deleted" 'tn a process sense) by the appropriate choice of tine constants. For exs 3 , units 8,10 , and 12 can be deleted by decreasing their tine constancs (TEMnx) to $0.01,0.01$, and 3 days, respectively, from the values 5, 5, and 400 days used in generating the Case 1 plots of PIgs. 2 to 6. Cross reduction of a tine constant [e.r., reducing raunx(12) to 0.001 davs] can lead to numerical instabilities, including the values of ${ }^{131}$ I flows beconing negative after periods corresponding to days or weeks of plant operation. This effect has not been investigated in wch detall; it is, however, associated with differences between nubers being very close to 0.0 .

\section{DISCUSSION AND CONCLUSIOAS}

Wany experimental data are needed in order to deternine the tinedependent flows and invertories of total lodine and ${ }^{131} I$ in a fuel reprocessing plant. These include the 13 paraneters listed in Table 1 and rate constant to calculate the 15 fractions $S(K)$ described by the firstorder time constants TEMM $X(K)$ in Sect. 2.* $\mathbf{A l}$ of these parameters are needed if the fuel reprocessing plant actually contains all of the units shown In Fig. 1. Excluding the values of Q0001(1) and Q0001(2), which are well known, the paraneters of Table 1 are probably uncertain by factors ranging from 1.25 to 10 , or larger. Hence, numerical values pertaining to the examples discussed in Sect. 4 are more qualftative than quantitative. Overall, calculated total-iodine RFs, Fig. 4, are consistent with those assmed or calculated in the steady state codels used in refs. 4 and 5. However, a few aspects do need further coment. First, plant

*TEAI X/6) is not actually used in model calculations because unit 6 is considered to be a permanent sink for lodine. 
RFs for ${ }^{131}$ I will exceed those for stable lodine by values in the range of $10^{*}$ (FIs. 4), including Case 1. Studies in which the capacities of units 15 and 16 are increased to any years, perhaps as long as the lifetine of the plant (Cases 3 and 4), show that the DP value of 131 I will exceed that of stable lodine by $10^{6}$ or wre. Such factors are considerably higher than those used in refs. 4 and 5 . Second, no studies described here are based on paraneters that would lead to the "near zero" release described br Iarbro, Harrington. and Jov;" 17 however, only a few of the parameters listed in Tables 1 and 2 would need to be changed to produce this near zero release. Changes that would be required are as follows: (1) Increase $A 3$ from 9 to 99 or 99.5 , corresponding to the evolution of 99 or 99.57 of lodine from the dissolver instend of the $90 \mathrm{z}$ used in all studles reported here; (2) increase DF2 to $10^{3}$ or $10^{*}$, corresponding to the use cf the Iodox process 11 or to the operation of a $\mathrm{Hg}\left(\mathrm{NO}_{3}\right)_{2}-\mathrm{HiNO}_{3}$ scrubber solution at a significantly higher efficiency than has been assuned thus far; 4,5 (3) increase $A 91$ to $10^{4}$ or $10^{6}$ from the value $10^{3}$ used in this report, corresponding to the ore complete discharge of lodine from unit 9 for permanent isolation in unit 19. Finally, it should be noted that the case studies reported here and nodifications that could lead to st11l greater retention of lodine are all based on the assuption that the process equipment containing lodine does not leak. Aby lodine leaking froe process equipment would enter the cell-ventilation off-zas equipment, thereby partially invalidating the nodel plant defined in P18. 1.

It is difficult to assess the accuracy of the assumption of firstorder kinetics, Eq. (22), as it applies to a process unit for lodine rewoval. The volunetric change in each unit due to lodine rewove ${ }^{*}$ (PIg. 1) is so sall that liquid and sol. phase processes ay be considerec in occur at constant volune. For example, an lodine flow of $\sim 10 \mathrm{~g}$-atoms/day in an LWR fuel reprocessing plant having a capactity of 5 metric tons (MT) of (uraniun + plutoniw) per day corresponds, et a maximum concentration of $300 \mathrm{~g}$ uranium/1iter, to a aximen of $0.0005 \underline{\mathrm{H}} \mathrm{I}$, or $0.00025 \underline{\mathrm{H}} \mathrm{I}_{2}$. Rewoval of all of tilis lodine would produce a trivial change in the volume of the dissolver solution in unit 3 of Pig. 1. As a second 
example, sorption of lodine on a $26 \%$ sllver-exchanged sodiun zeolite ${ }^{18}$ u1l probably not exceed 25 to $50 \mathrm{~m}$ of lodine per aflliliter of zeolite before the zeolfte is replaced; this corresponds to less than a 12 change in the volune of the seolite.

Without going into detalls, such es those found in ref. 19, the nearly-constant-velune process of lodine renoval in each of the many units of an wh fuel reprocessing plant vould appear to be fairly accurately represented by first-order kinetics. This coment applies to the following potential process unics: (1) a batch dissolver and (2) a continuous dissolver, the solvent extraction systen, or distillation units which nearly correspond to back-aix flow reactors. Sorption on sfiver zeolite or on ion exchange resin are probably nore accurately represented by the plug-flow processes. 19

The present wodel of lodine transport and chenical reaction or physical retention is capable of being accomodated to any ixperimental data that ay be obtained in the future. For example, no difficulty would be encountered if any, or all, of the rate processes were found to require replacement of first-order kinetics by wore complicated processes. Each replacenent of a first-order kinetic equation, as in Eq. (22), would be simple from the standpoint of computer programing. Su?h replacenent would produce sall changes in the curves of Figs. 2 to 12 but could not produce major changes.

\section{REFERENCES}

1. "Environental Radiation Protection Standards for Nuclear Power Operations," Enviromental Protection Agency (40 CPR Part 190 Subchapter F - Radiation Protection Programs] [FRL 659-6], Fed. Reg1st. 42, 9-Thursday (Jan, 13, 1977).

2. Environmental Radiation Protection Requirements for Hormal Operations of Activities in the Uranium Fuel Cycle, Final Environmental Statenent (40 CFR 190), EPA 520/4-76-016 (Nov. 1, 1976). 


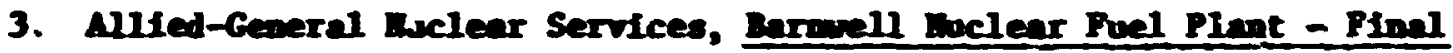
Safety Anelyile Report, Docket Do. 50-332 (Oct. 10, 1973).

4. B. C. Fluney, R. B. Blenco, R. C. Dahlem, F. G. Eltts, and J. P. Witherspoon, Correlation of Bedioective Heste Treatnent Costs and the Builronental Iact of Wate Effluents in the nuclear Poel Orcle for Dae in Eotablishing "as Los as Practicable" Guides - Duclear

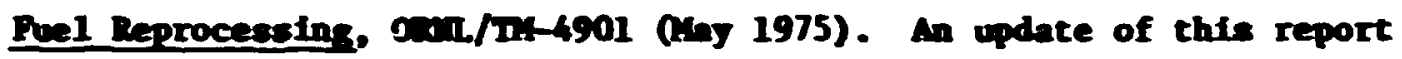
Is as follows: B. C. PInney, R. E. Manco, R. C. Dahtman, G. S. Will, F. G. Kitts, R. E. Hoore, and J. P. Wtherspoon, correlation of Podioctive Wate Irentent Costs and the Rovironental Iract of Wate Effluents in the buclear Puel Ocle - Reprocesein Lifht-linter

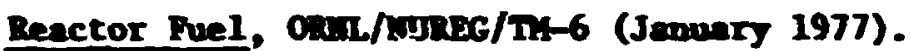

5. W. Davis, Jr., R. E. Blanco, B. C. Finney, G. S. Bill, R. E. Hoore, and J. P. Witherspoon, Correlation of Radioactive Waste Treatient Costs and the Enviromental Inpact of Haste Effluents in the Huclear Puel Crcle - Reprocessing of High-Tenperature Gas-Cooled Reactor Puel Concaining ${ }^{23} \mathrm{~J}$ and Thoriue, ORJ/RUReg/Mt-4 (May 1976).

6. E. R. Irish and U. B. Reas, "The Purex Process - A Solvent Extraction Hethod for Irradiated Uranium," Pp. 83-106 in Syzposive on the Reprocessing of Irrediated Puels Beld at Brusgels, Belgiun Hay 20-25, 1957, USAEC, TID-7534.

7. W. Davis, Jr., Yodels for Calculating the Effects of Isotopic Exchange, Radiaactive Decay, and of Recycle in Renoving Iodine fron Gas and Liquid Streams, Omn-5060 (September 1975). See also, Tucl. Sc1. Eng. 61, 11 (1976).

8. J. H. Goode (compller and ed.), Voloxidation-Reoval of Volatile Fission Products from Spent LPBR Puels, ORNL/TH-3723 (January 1973).

9. H. Beaujean, H. Bohnenstingl, M. Laser, E. Mrrz, and H. Schnez, "Gaseous Radioactive Bnissions from Reprocessing Plants and Their Possible Reduction," in Syeposiue on Environeental Behavior of Radionuclides Releaged in the Muclear Industry, Alx-en-Provence, Prance, Hay 14-18, 1973. 
10. Chen. Technol. Div. Amou. Prot. Dep. My 31, 1970, OAI-4572, P. 69.

11. G. I. Cachers and U. E. Shockley, "Rewoval of Organic and Inorganic Iodine from a Gaseous Atrosphere," J.S. Patent 3,752,876 (Ang- 14, 1973).

12. G. I. Cathers and C. J. Shipman, "Renowal of Iodive from Hitric Acid Solutions," 0.S. Patent 3,792,154 (Feb. 12, 1974).

13. G. I. Cathers and C. J. Shipen, Tethods for Renoving Iodtne fron GItric AcId," U.S. Patent 3,803,295 (Apr. 9, 1974).

14. B. W. Godbee, Dase of Evaporation for the Treatent of Liguids in the Fuclear Industry, oul-4790 (Septe-ber 1973).

15. R. G. Edurards and R. E. Punderlic, "Matrix Equation Solver" in The Conputing Technolon Center Merfeal Analysis Library, ed. by G. W. Westley and J. A. Watts, CTC-39 (Oct. 6, 1970).

16. F. D. Bnmerling, "Subroutine IUTA" in The Conputias Techoolon Cencer threrical inaljsis Librar, ed. bJ G. W. Westley and J. A. Hates, CTC-39 (Oct. 6, 1970).

17. 0. 0. Yarbro, R. E. Harrington, and D. S. Joy, Effluent Control in Puel Reprocessing Plants, Oris' 'TH-3899 (Karch 1974).

18. R. D. Ackley and R. J. Davis, Effect of ixtended Exposure to Simulated LFPR Fuel Reprocessing off-Gas on Radiolodine Trapping Perfornance of Sorbents (PInal Report), ORru/Th-4529 (August 1974).

19. 0. Levensplel, Cheaical Reactor Engineering, J. Hiley and Sons, I. Y., 1962. 
BLANK PAGE 


\section{APPENDICES}

APPEDIX A. EVALUATION OF IODINE FLON RATES

As noted in Sect. 2, the wodel of this report is based on the assuptions that (1) each equipment unit through which lodine flows has a definable axtim capacity (holdup) for lodine and (2) the rate at which lodine leaves the unit is proportional to the degree of saturation of this maximu and to the rate at which lodine enters the unit. For unit 1 , the codel therefore corresponds to:

$$
\operatorname{DER}(1, \mathrm{~L})=[Q 0001(1)-T(1)] *[1-S(1)] \text {, }
$$

or to the equivalent form

$Q 0102(L)+Q 0103(L)=[Q 0001(1)-T(1)] * S(1)$.

In Table 1, the experimental datu $A 1$ provides the equation:

$Q 0102(L)-A 1 * Q 0103(L)=0$.

From Eqs. $(A-2)$ and $(A-3)$ we thus obtain

$$
Q 0103(\mathrm{~L})=[Q 0001(\mathrm{~L})-T(1)] * S(1) /(1+\mathrm{A} 1) \text {. }
$$

and from Eq. $(A-3)$ we obtain

$$
Q 0102(L)=A 1 * Q 0103(L) \text {. }
$$

Equations corresponding to other units are as follows;

Unit 2:

$$
\begin{gathered}
Q 0209(\mathrm{~L})+Q 0216(\mathrm{~L})-\mathrm{Q} 0402(\mathrm{~L}) * \mathrm{~S}(2)-\mathrm{Q} 0502(\mathrm{~L}) * \mathrm{~S}(2)= \\
{[\mathrm{Q} 0102(\mathrm{~L})+\mathrm{Q} 1202(\mathrm{~L})+\mathrm{Q} 1402(\mathrm{~L})-\mathrm{T}(2)] * \mathrm{~S}(2)}
\end{gathered}
$$

and

$$
Q 0209(\mathrm{~L})+Q 0216(\mathrm{~L}) *(1-\mathrm{DF} 2)=0 .
$$

Unit 3:

$$
Q 0304(\mathrm{~L})+Q 0305(\mathrm{~L})-Q 1303(\mathrm{~L}) * S(3)=[Q 0103(\mathrm{~L})-\mathrm{T}(3)] * \mathrm{~S}(3)
$$

and 


$$
\text { Q0304(L) }-90305(L) * A 3=0
$$

Onte 4:

$$
Q 0402(L)+Q 0409(L)-Q 0304(L) * S(4)=-S(4) * T(4)
$$

and

$$
\text { Q0402(L)*(DF4-1)-Q0409(L) }=0 \text {. }
$$

Unit 5:

$$
\begin{aligned}
& -00305(\mathrm{~L}) * S(5)+Q 0502(\mathrm{~L})+Q 0506(\mathrm{~L})+Q 0507(\mathrm{~L})=-S(5) * T(5), \\
& Q 0502(\mathrm{~L}) *(1-\mathrm{AS1})-Q 0506(\mathrm{~L}) * A 51-Q 0507(\mathrm{~L}) * .51=0,
\end{aligned}
$$

and

$$
-00502(\mathrm{~L}) * A .52+Q 0506(\mathrm{~L}) *(1-. .52)-0.0502(\mathrm{~L}) * A .52=0 .
$$

Dnit 6:

This is the solvent purification unit; the cquations refer to the net accumulation of lodine. Thus, this unit is treated as a perwanent sink for lodine, which is lost only by radioactive decay.

Unit 7:

$$
-Q 0507(\mathrm{~L}) * S(7)+Q 0713(\mathrm{~L})+Q 0714(\mathrm{~L})=-3(7) * \mathrm{~T}(7)
$$

and

$$
\text { Q0713(L)*(DP7-1)-Q0714(L) }=0 \text {. }
$$

Unit 8:

$$
Q 0810(\mathrm{~L})+Q 0815(\mathrm{~L})-Q 1008(\mathrm{~L}) * S(8)-Q 1308(\mathrm{~L}) * S(8)=-S(8) * T(8)
$$

and

$$
-Q 0810(L)+Q 0815(L) *(D F 8-1)=0 .
$$

Unit 9:

$$
-Q 0209(\mathrm{~L}) * S(9)-Q 0409(\mathrm{~L}) * S(9)+Q 0910(\mathrm{~L})+Q 0919(\mathrm{~L})=-S(9) * T(9)
$$

and

$$
-Q 0910(L) *(1-A 91)+Q 0919(L) * A 91=0 .
$$


Unit 10:

and

$-Q 0810(\mathrm{~L}) * S(10)-Q 0910(\mathrm{~L}) * S(10)+Q 1008(\mathrm{~L})+Q 1011(\mathrm{~L})=-S(10) * T(10) \quad(A-21)$

$Q 1008(\mathrm{~L}) \star(D F 10-1)-Q 1011(\mathrm{~L})=0$.

Unit 11:

This is the MUU storage tank systen. Iodine leaves this unit only if it is purged, or sparged, at a rate

Q1: $12(1)=R+\operatorname{EN}(11, L)$,

where $R$ is the sparge rate in units of day $^{-1}$ and $E N(11, L)$ is the inventory of component $L$ in unit 11 .

Unit 12:

$$
\begin{aligned}
Q 1202(\mathrm{~L}) & =[\mathrm{Q} 1112(\mathrm{~L})-\mathrm{T}(12)] * S(12) \\
& =\left[R^{\star} \operatorname{ENS}(11, \mathrm{~L})-\mathrm{T}(12)\right] * S(12) .
\end{aligned}
$$

Unit 13:

$-Q 0713(1) * S.(13)+Q 1303(L)+Q 1308(L)=-S(13) * T(13)$

and

$$
Q 1303(\mathrm{~L}) \star(\mathrm{Al3}-1)+\mathrm{Q} 1308(\mathrm{~L}) \star_{\mathrm{A} 13}=0 .
$$

Unit 14:

This is a permanent HLH storage system that is vented to the off-gas system. The rate of venting is considered to be operator-controlled according to

$$
\text { Q1;02(L) = HLVENT*EN }(14, L) \text {, }
$$

where HLVENT is a vent rate (similar to $R$ ), In units of day ${ }^{-1}$, and $E N(14, L)$ is the inventory of component $L$ in init 14 .

Unit 15:

$$
Q 150 E(L)=[20815(L)-T(15)] * S(15) \text {. }
$$

Unit 16:

$$
Q 160 E(L)=[Q 0216(L)-T(16)] \star S(16) \text {. }
$$


Onit 17:

This is the envirowent, which receives lodine due to the vaporization of lodine-containing excess weter from the plant. This is a permanent sink for lodine, which ir lost ouly by radioactive decay.

Dnit 18:

This is the enviroment, which recelves indine from the off-gas systen. This, also, is a pernanent sink for lodine, which is lost only by radioactive decay.

Dnit 19:

This is a perament sink corresponding to any method of permanent renoval of lodine fron the system.

Equations $(A-4),(A-5),(A-23),(A-24)$, and $(A-27)$ can be solved for values of Q0102(L), Q0103(L), Q1202(L), and Q1402(L;. These four flow rates plus Q0001(L) are then used in the 18 by 18 atrix Eq. (29) to solve for Q0209(L), Q0216(L), Q0304(L), Q0305(L), Q0402(L), Q04C9(L), Q0502(L), Q0506(L), Q0507(L), Q0713(L), Q0714(L), Q0810(L), Q0815(L), Q0910(L), Q1008(L), Q1011(L), Q1303(L), and Q1308(L). Three of these 18 flow rates, namely Q0815(L), Q0216(L), and Q0910(L), are then used to solve for the three remaining flows Q1S0E(L), Q160R(L), and Q0919(L). 
APPEDIX B. DEFInITIOAS AND VALUES OF PARALTERS

The values of Iranu(x) defined in this report are not the sane as those that would norally be deternined in laboratory experinents. In the latter, a constant flow of lodine in a liquid or gas strea would be used to introduce this element into some type of sorber; in a fuel reprocessing plant, this inlet flow would continually increase until the preceding unit(s) was(were) saturated with lodine. Thus, for exaple, the constant used for the lodine-sorber unit 2 (Fig. 1) will be influenced by the buildup of lodine in units 1,4,5, 12, and 14. Individual values of Tanix(K) are described as follows.

TEanx(1) = the holdup-tine constant of fodine in a head-end voloxidizer or grapinite burner. It is presuned to be on the order of a few hours, or 20.1 days, in units consistent with those used in this report.

TEinx(2) = the holdup-time constant of lodine in the primary lodine sorber in the off-gas systen. If unit 2 is a $\mathrm{Hg}\left(\mathrm{NO}_{3}\right)_{2}-\mathrm{HHO}_{3}$ scrubber and if this solution is continuously partially replaced, then the equivalent holdup time ay be $\sim_{1}$ week. Concentrated nitric acid of the Iodox process ${ }^{11}$ or an efficient wetal-exchanged zeolite wight provide holdup times significantly longer.

TEMax(3) = the holdup-time constant of foding in the unit in which $\mathrm{UO}_{2}, \mathrm{PuO}_{2}, \mathrm{ThO}_{2}$, etc., of the nuclear fuel, are dissolved. This tine is in the order of a few tenths of a day.

TEMAX(4) = the holdup-time constant of fodine in any lodine-retention unit in the dissolver off-gas streas. This may be as long as 8 days if a $\mathrm{Hg}_{8}\left(\mathrm{NO}_{3}\right)_{2}-\mathrm{HHO}_{3}$ scrubber solution is used and as short as 0.01 days if no such unit is used.

TEMAX (5) - the holdup-time constant of lodine in the solvent extraction systea. This is probably in the order of a few tenths to $0 . j$ days. 
Tanur(6) = the boldup-tine constant of sodine in the solvent recovery (repurification) system. Iodine arriving at this unit, wich way be a $\mathrm{Ka}_{2} \mathrm{CO}_{3}-\mathrm{HaOA}$ scrubber-washer system, is not expected to return to the solvent extraction system. For this reason, there is no flow from unit 6 [see Fig. 1 and Eq. (6)], and TBMnx(6) is not actually used in the nodel; It is assigned a nonzero value, such as $1 . \mathrm{D}+6$ days, for convenience.

Iangr(7) = the holdup-time constant of fodine in a HIH aqueous waste evaporator. This is presumed to be $n_{1}$ to 3 days.

Thinu (8) = the holdup-tine constant of lodine in the Iodine-rewoval partial evaporator. It is considered to require a small number of days to approach steady state operation.

$\operatorname{ramax}(9)=$ the holdup-tive constant of lodine in what ay be a neutralization unit fron wich lodine way be discharged for peranent isolation. The retention time will probably be only a few days.

TEanX $(10)=$ the holdup-time constant of lodine in the MW evaporator. If such a unit is used, the time constant way be on the order of a few days.

Tagax(11) = the holdup-tine constant of lodine in the MH storage tank. The holdup-tine is assumed to be very long and set equal to $1 . D+6$ days in this study.

TENAX(12) = the holdup-tine constant of lodine in any unit through which sparge gas fron the MLH storage tank passes before reaching the off-gas system. This time will be short ( 0.01 to 1 day) if no such untt is used and may range from many days is many years tf, for example, a silver-exchanged zeolite is used.

Temenx(13) = the holdup-time constant of lodine in the nitric-acid recovery system. This w11 be on the order of a few days. 
$\operatorname{Imanx}(14)=$ the holdup-tine constant or lodine in the HLH storage systen (probably very long unless this systen is cousidered to include vaste solidification). A value of $1 . \mathrm{D}+6$ is used in this study.

TEanx(15) = the holdup-tine constant of lodine in the lodine-rewoval Ion exchange. This constant will range from hemdreds of days to any years when such a unt is used.

Tankx(16) = the holdup-tine constant of lodine in the silver-exchanged zeolite of the off-gas systen. It will range from hundreds of days to many years. 


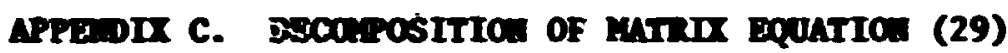

The eatrix Eq. (29) can be decomposed Into a 9 by 9 , a by 4, and a 5 by 5 merix, shown is Eqs. (C-1) to (C-3). To take adventage of this decompostion, these equations aust be solved in the order listed since flows Q0304 and Q0502 deternined in Bq. (C-1) are used in Eq. (C-2); fion Q1308 fron Eq. (C-1) and flows Q0209 and Q0409 fron Eq. (C-2) are used in Eq. (C-3). Several tine checks show that a computer progra based on solving these three saller antrices extecutes and prints $130 \mathrm{z}$ faster then a progran based on the 18 by 18 metrix of Eq. (29). However, the progran listed in this appendix is based on Eq. (29).

Saples of calculations shown in Figs. 2 to 12 peitain to an initially "new" plant; shat is, one not exposed to lodine before the zero tine of these plots. The computer programs are not so restrfeted; instead, SUBRourhiE FRP requires that initial inventories be provided as input. All Input values of infital inventories were set to zero in this example. 
0
8
2
0
3
1
$\frac{1}{8}$
8

ב্
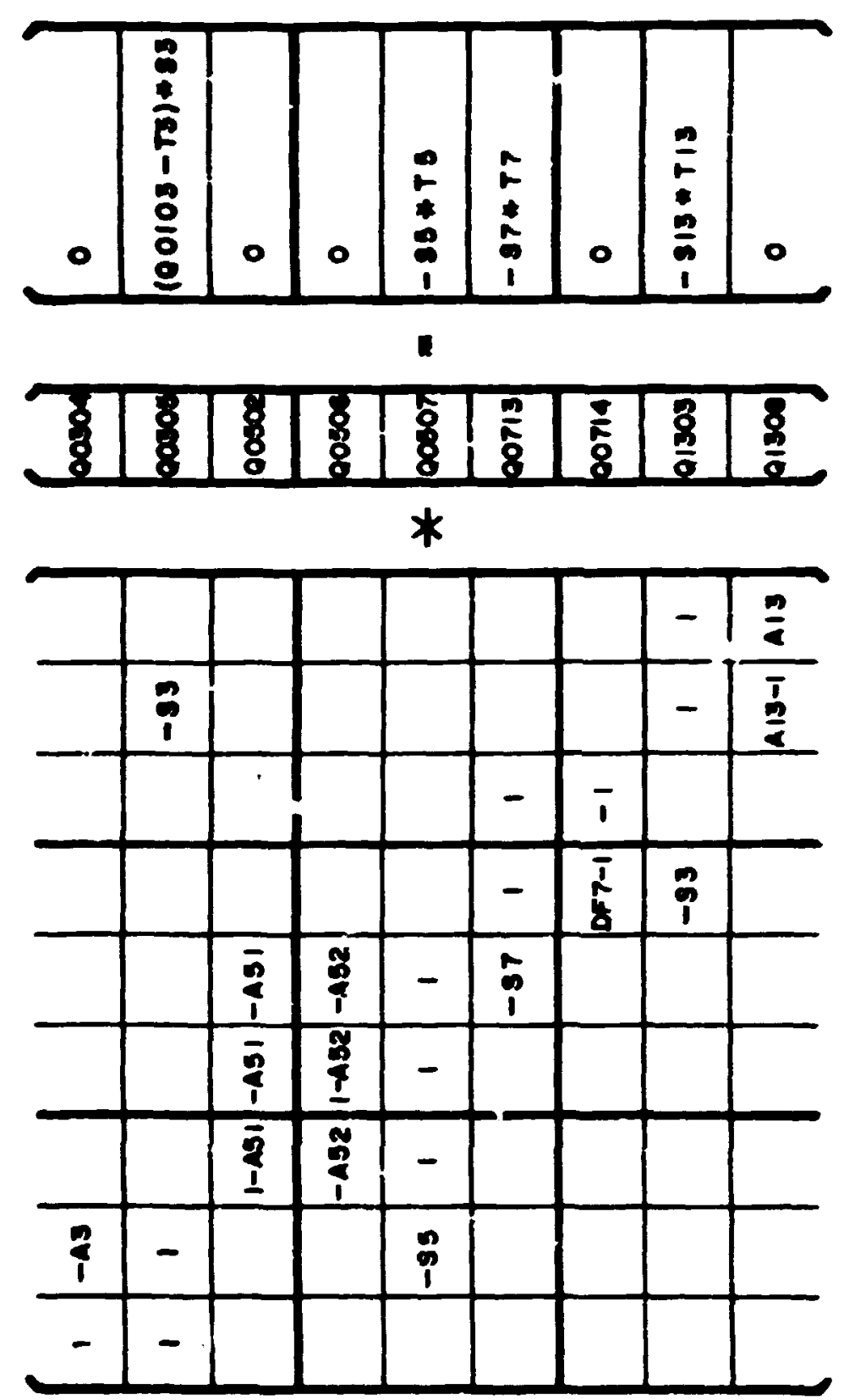
$\overline{8}$
1
8
0
8
$\frac{2}{2}$
$\frac{2}{0}$

a

กิ
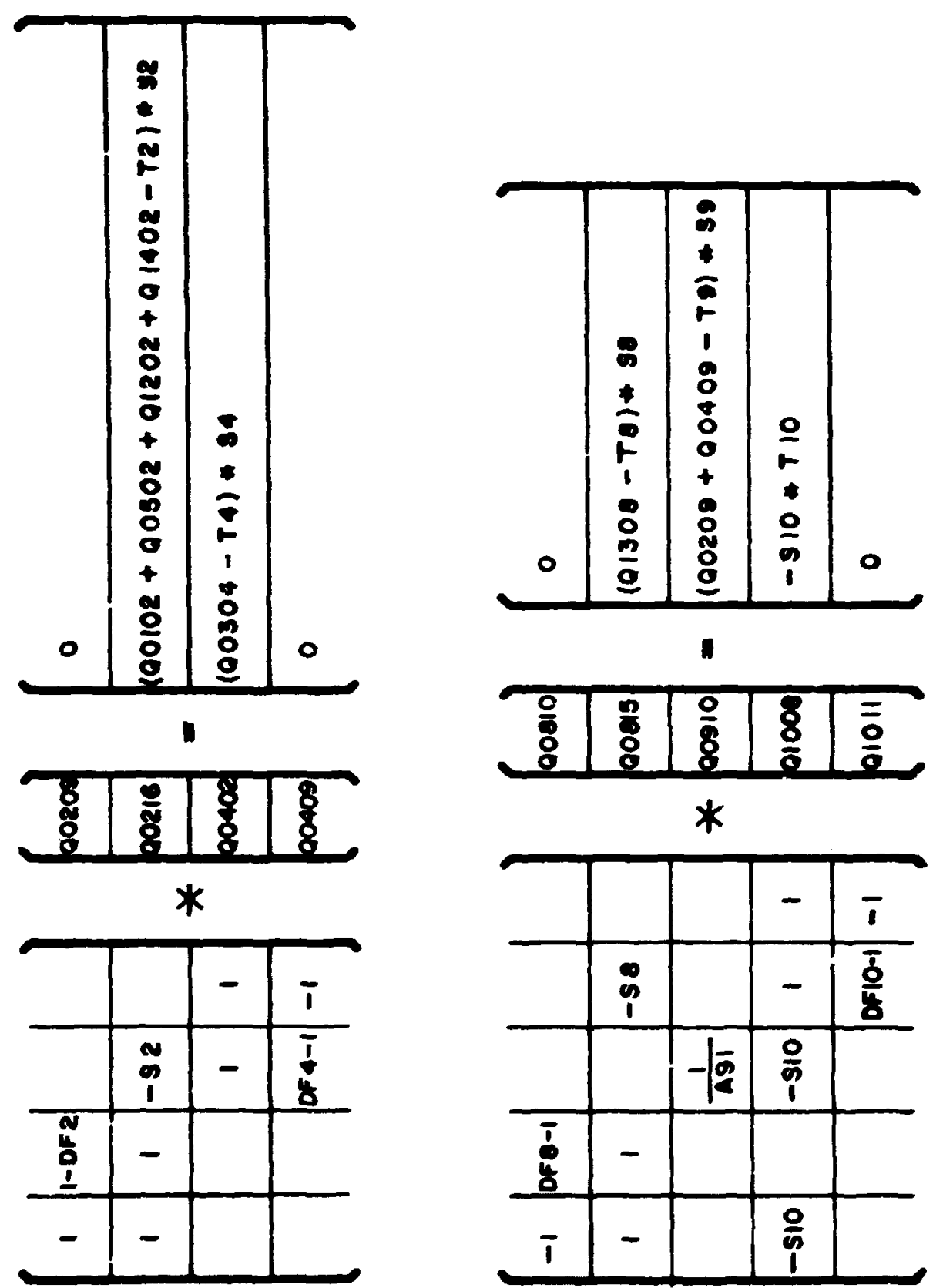


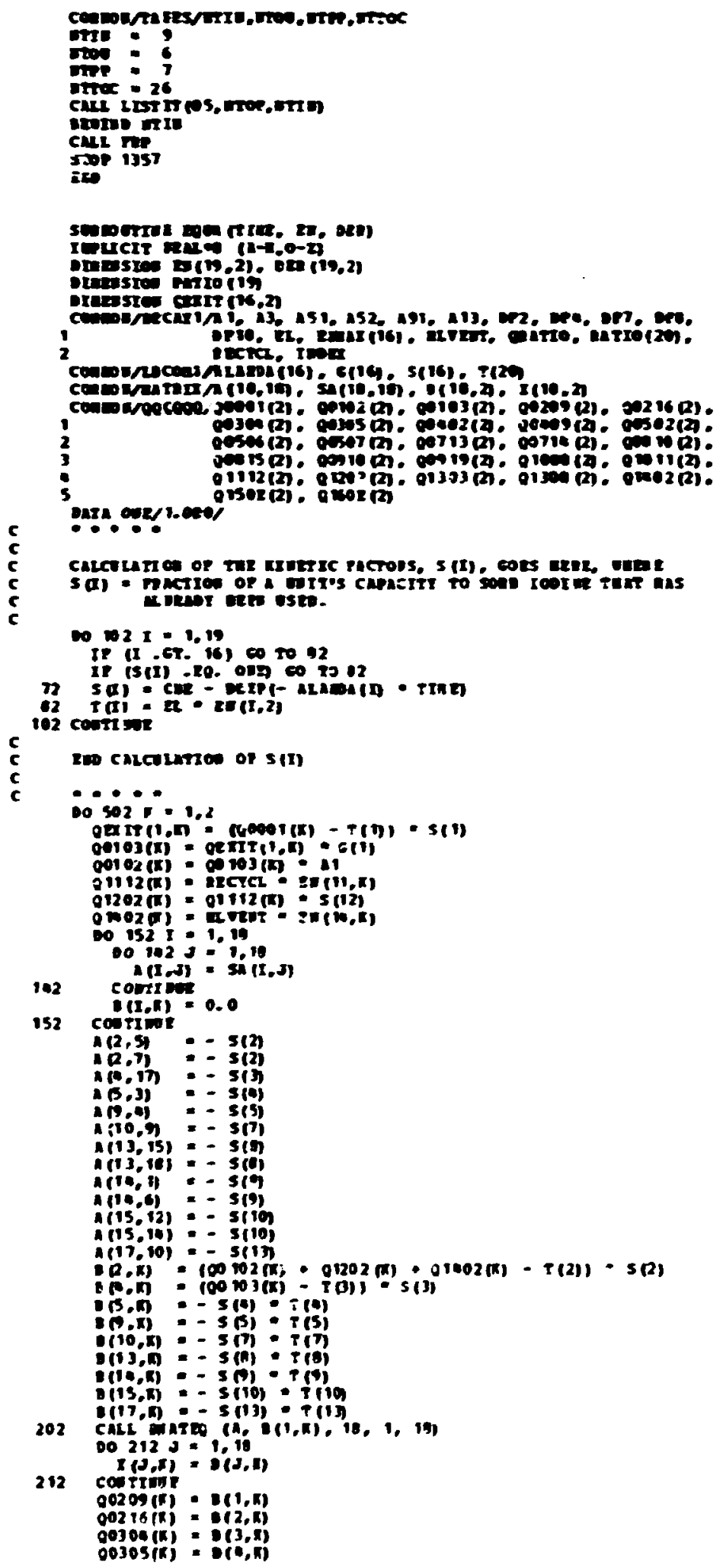




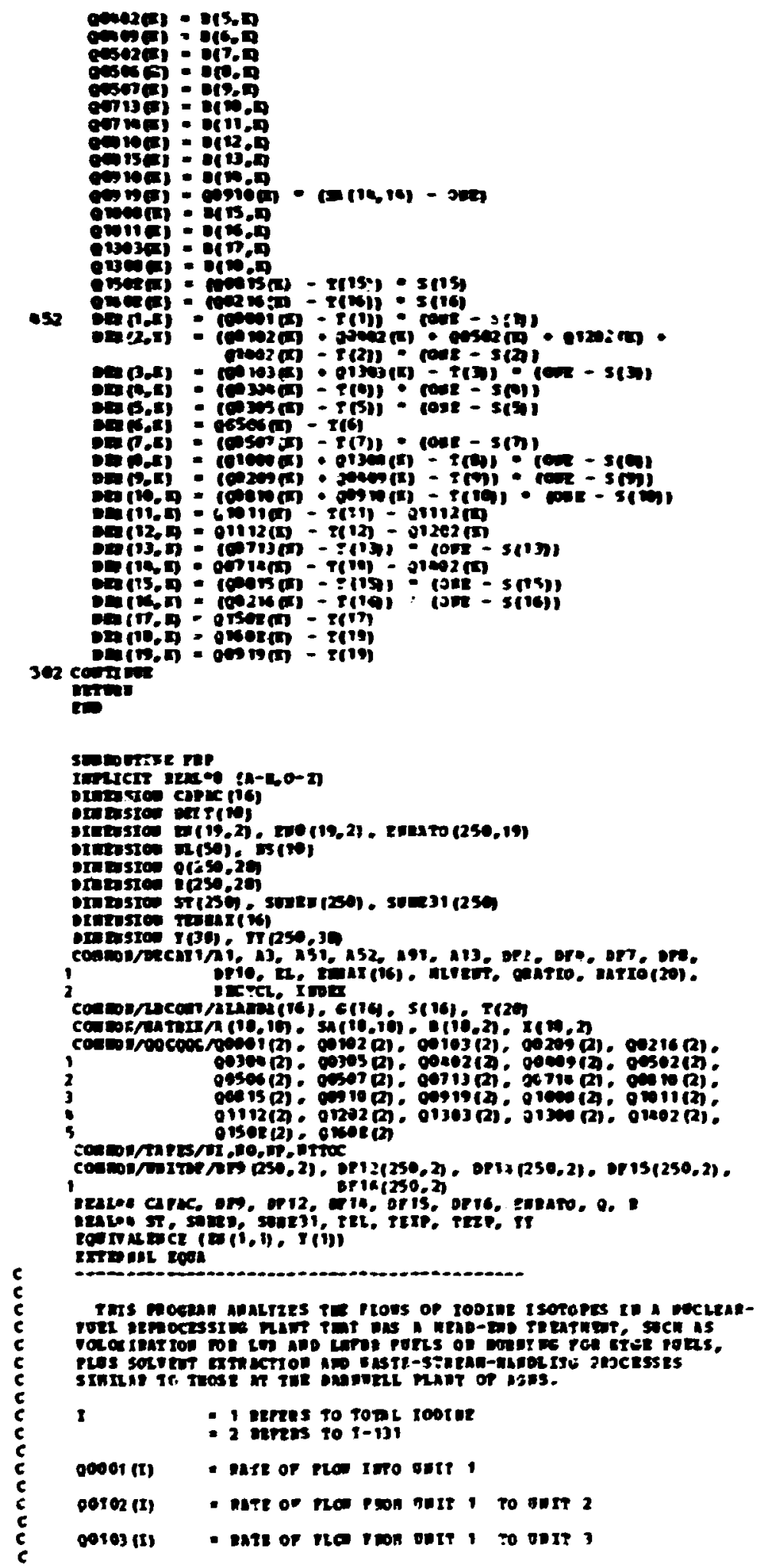




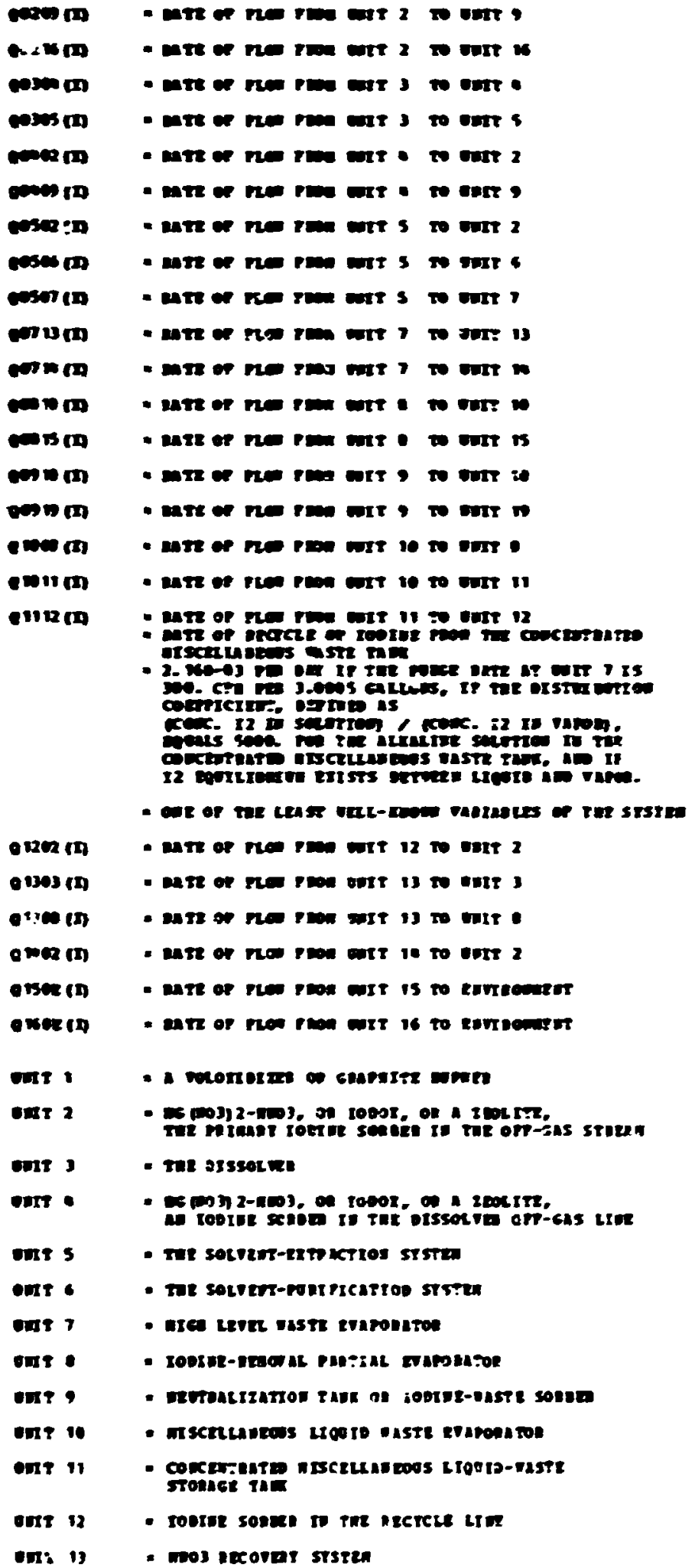




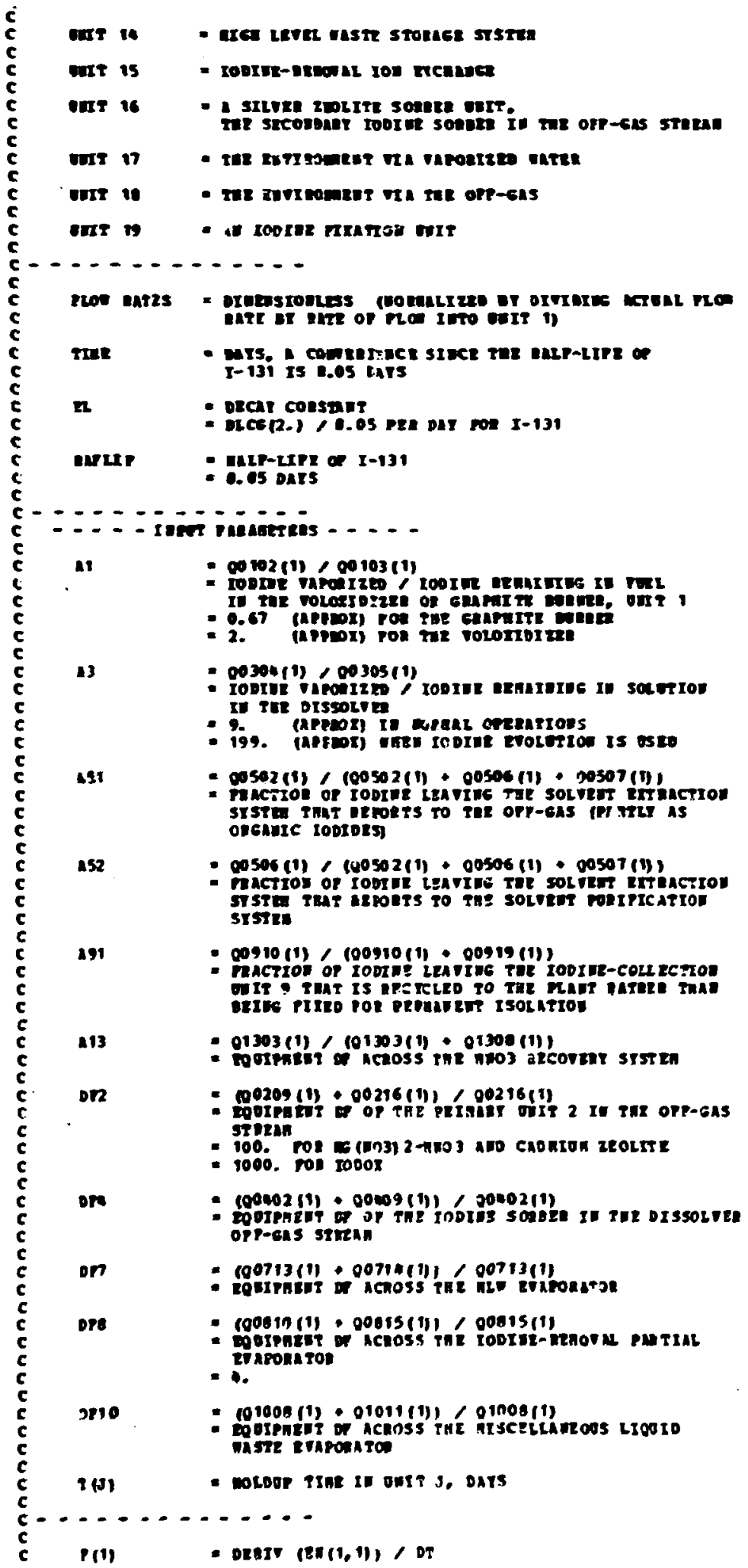




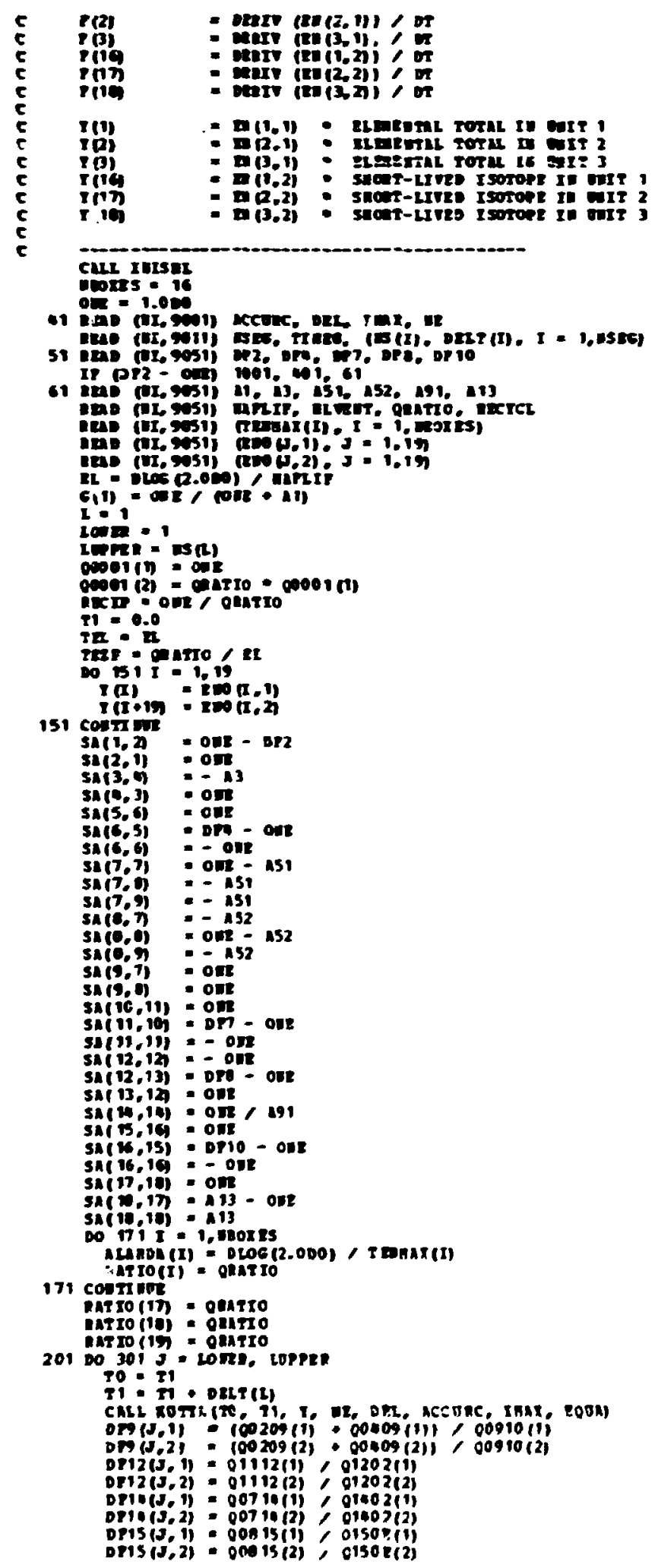




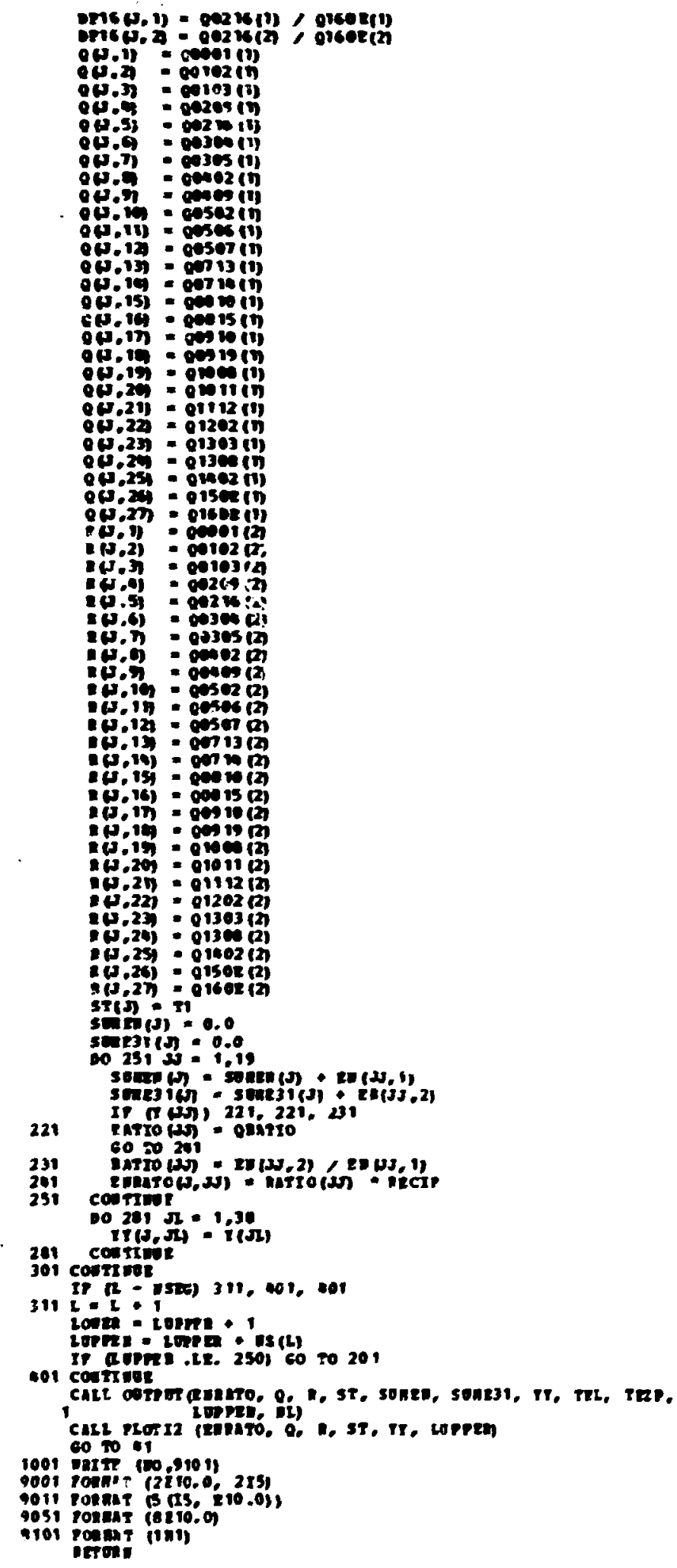




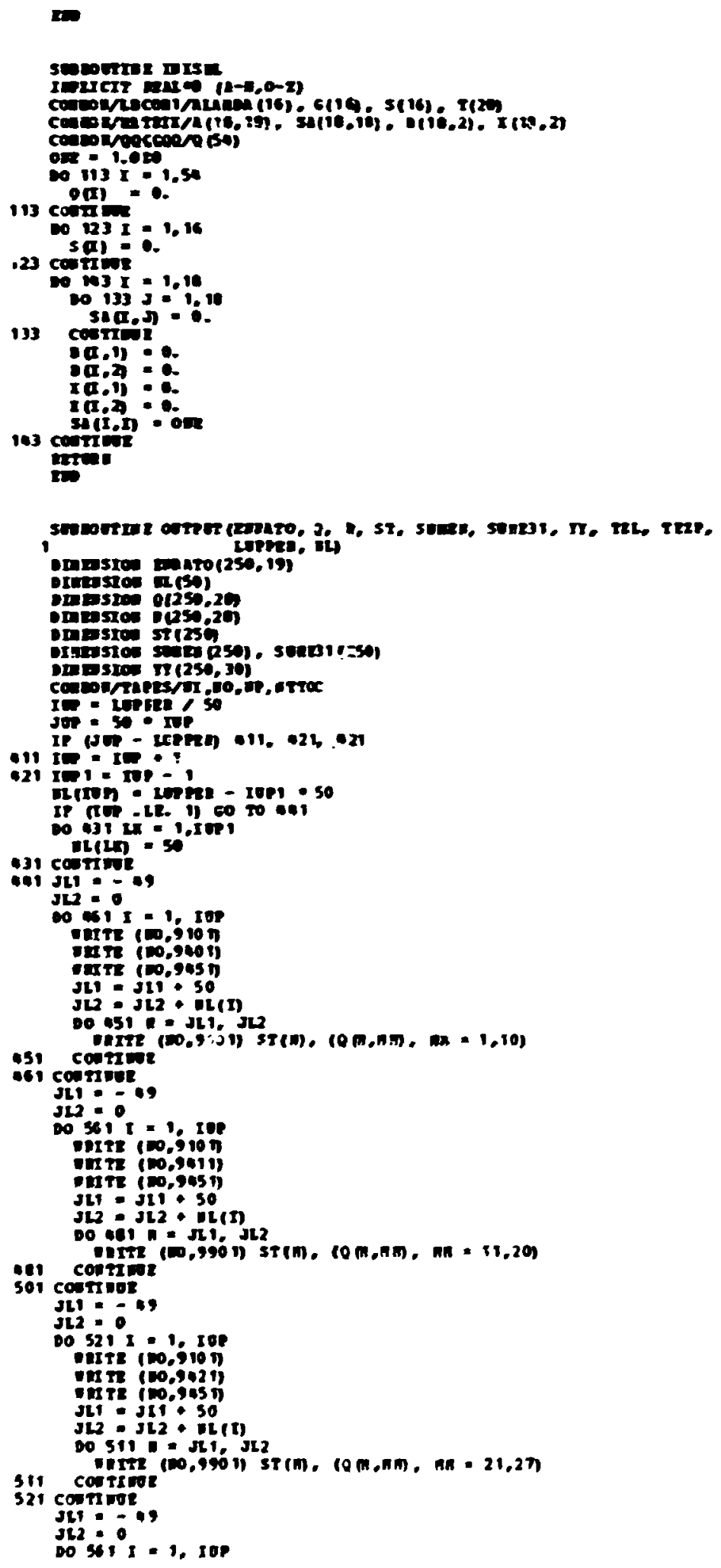




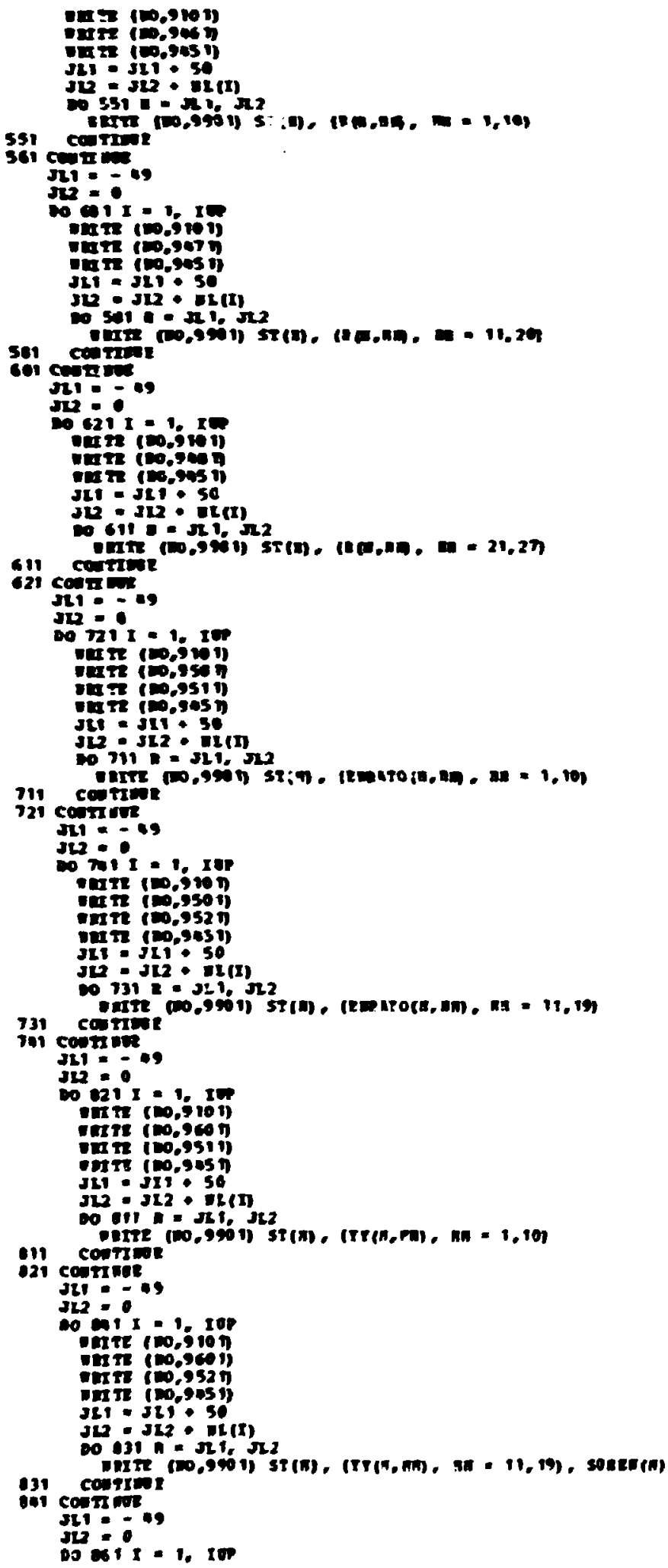




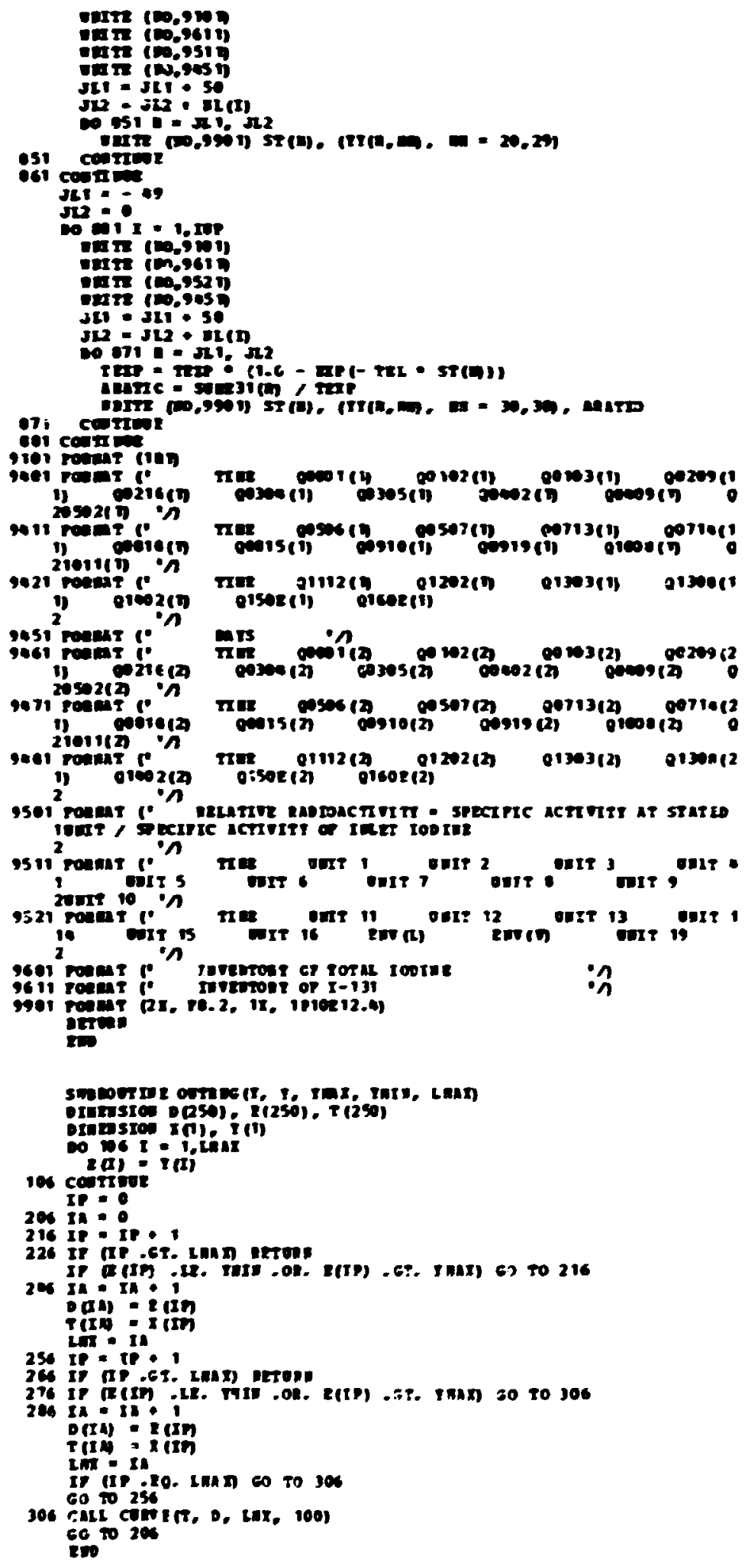




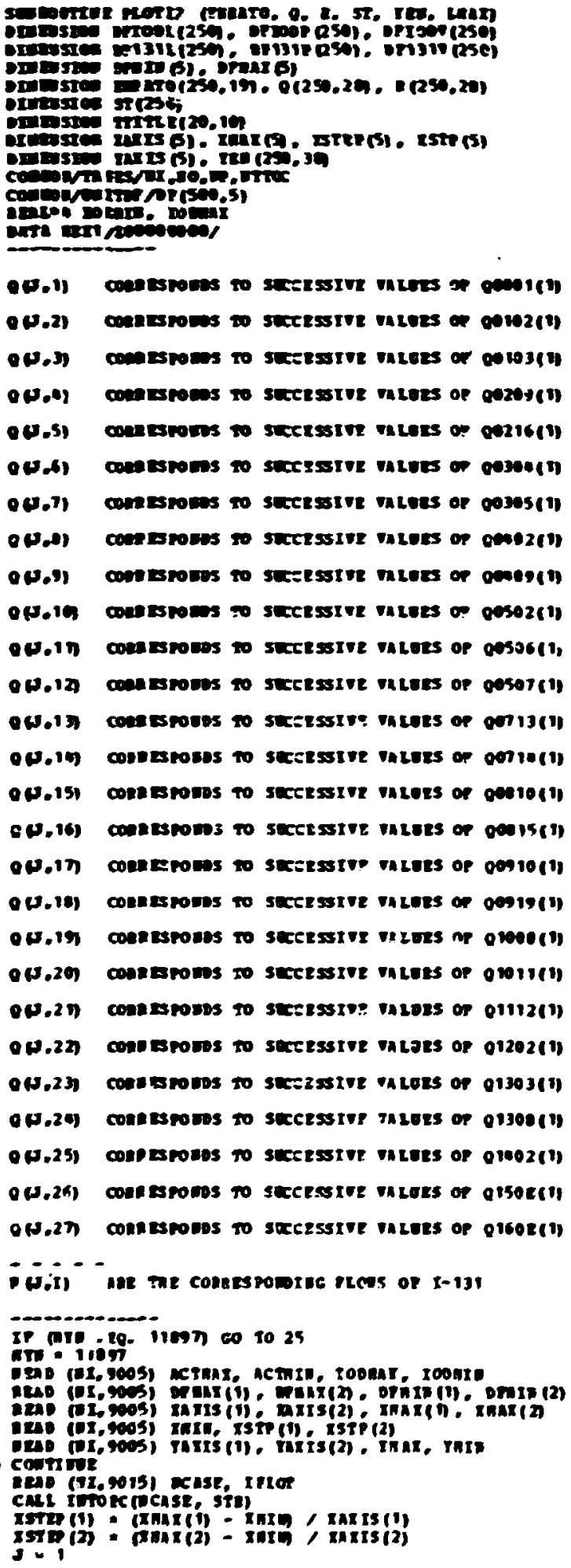




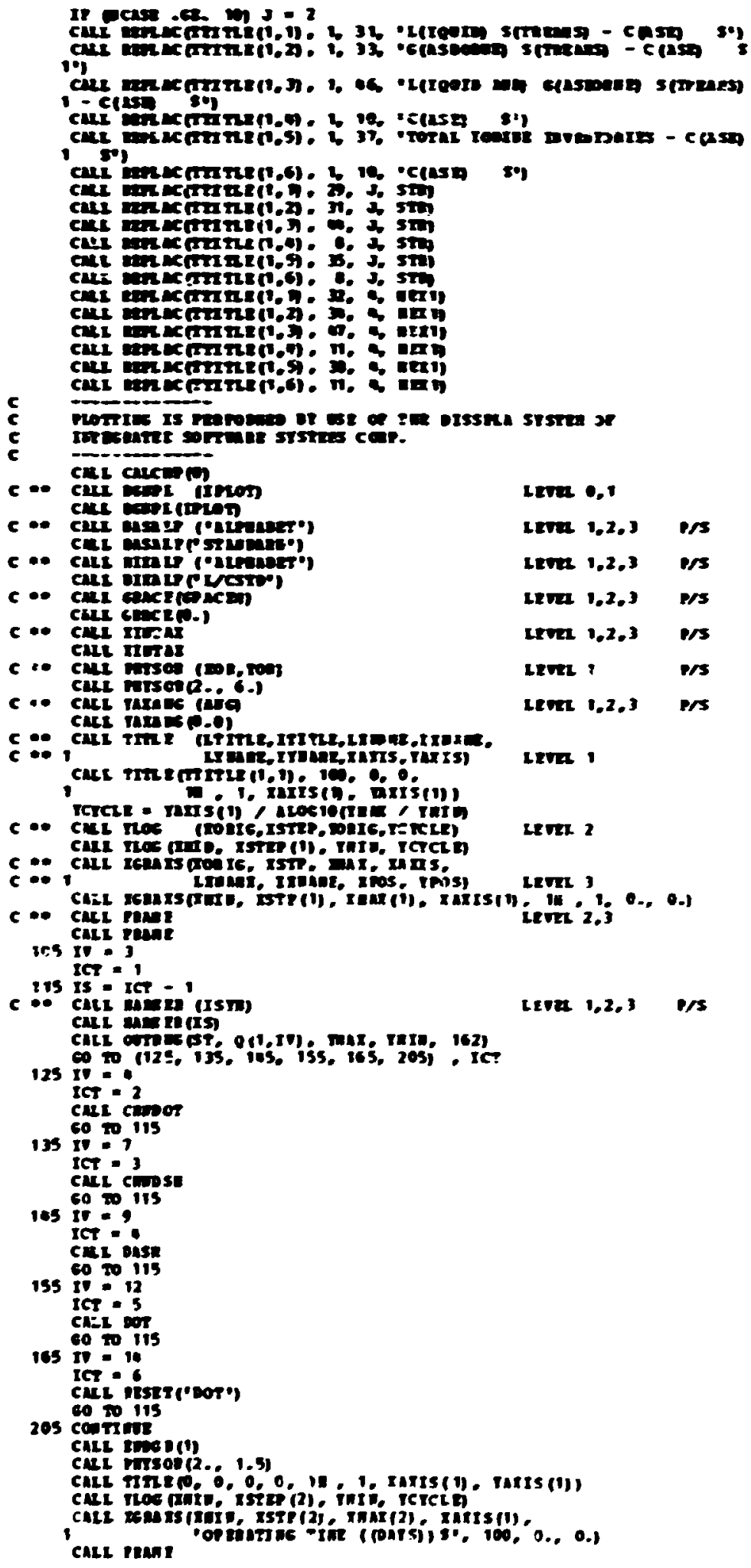




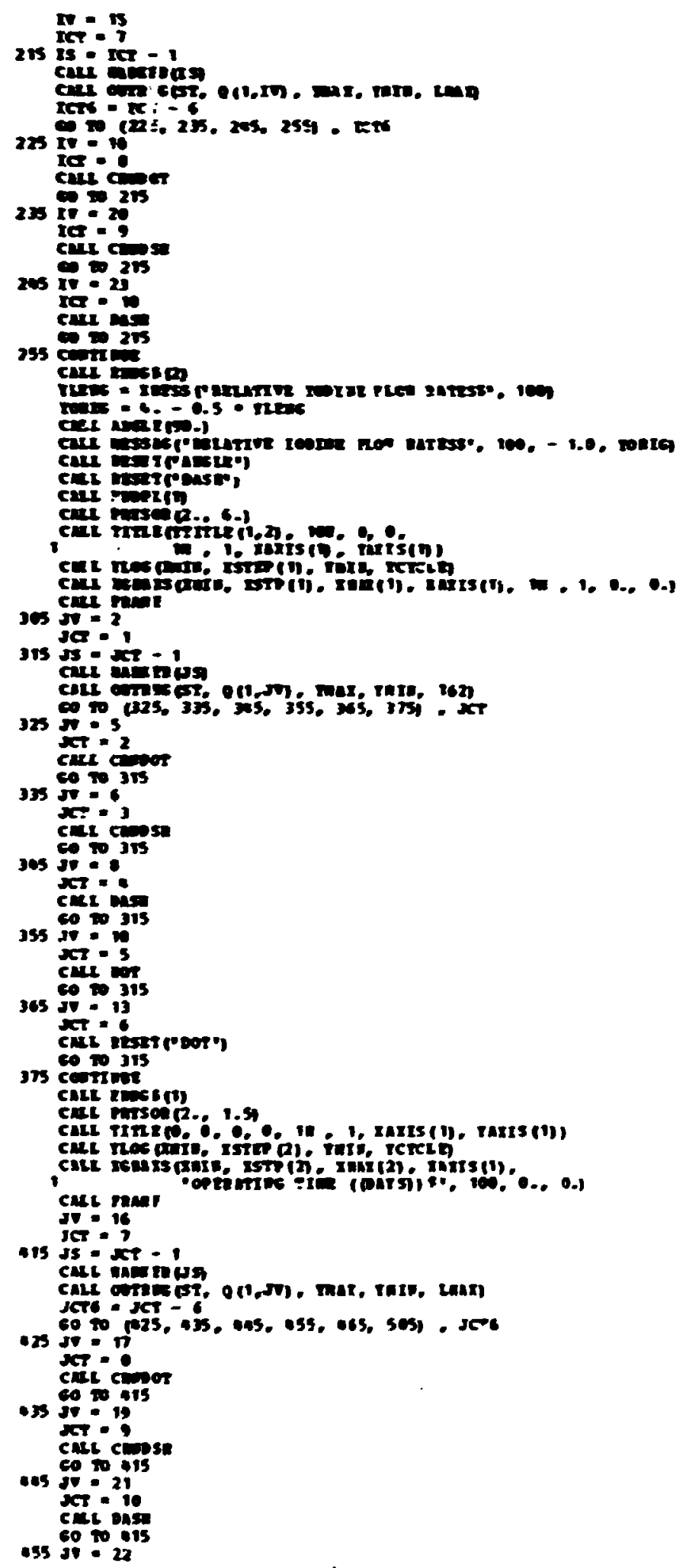




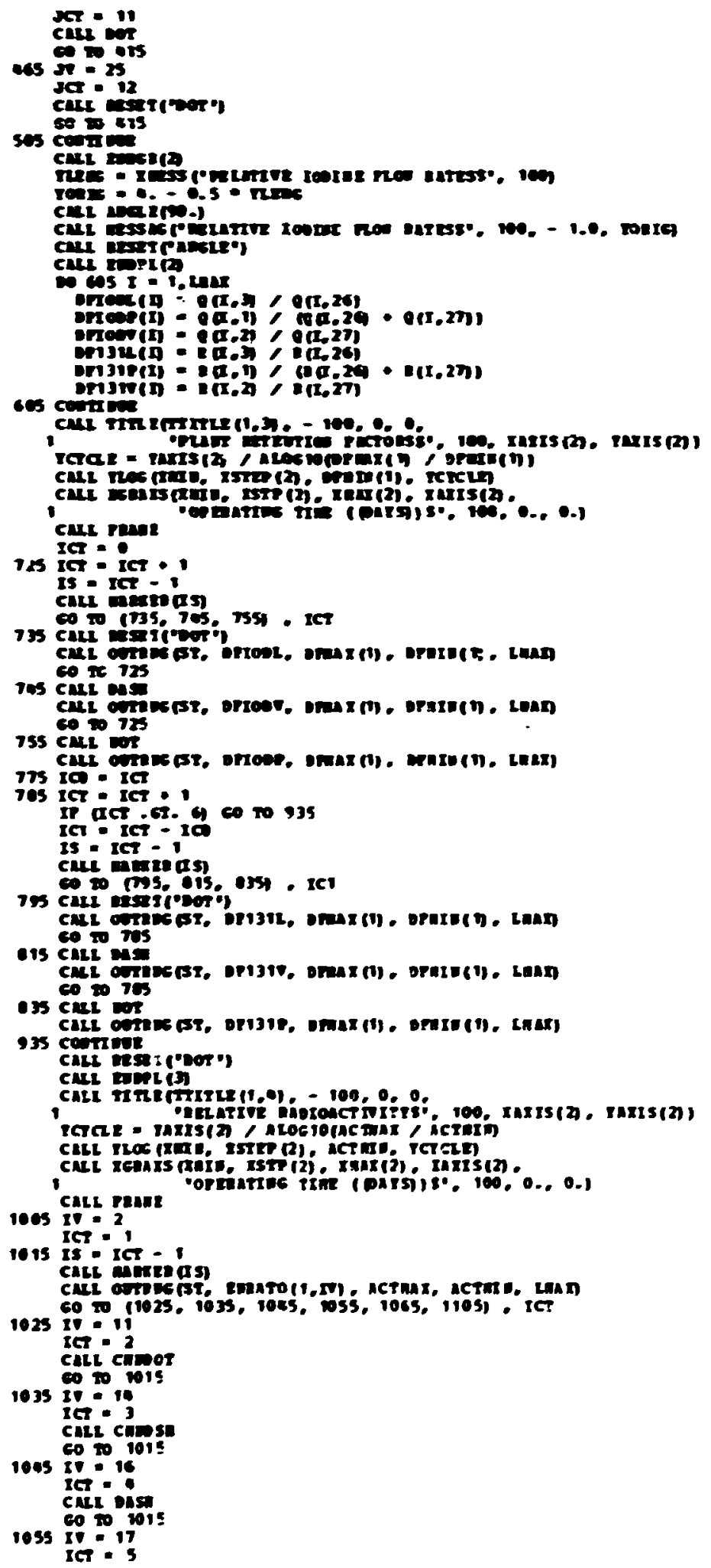




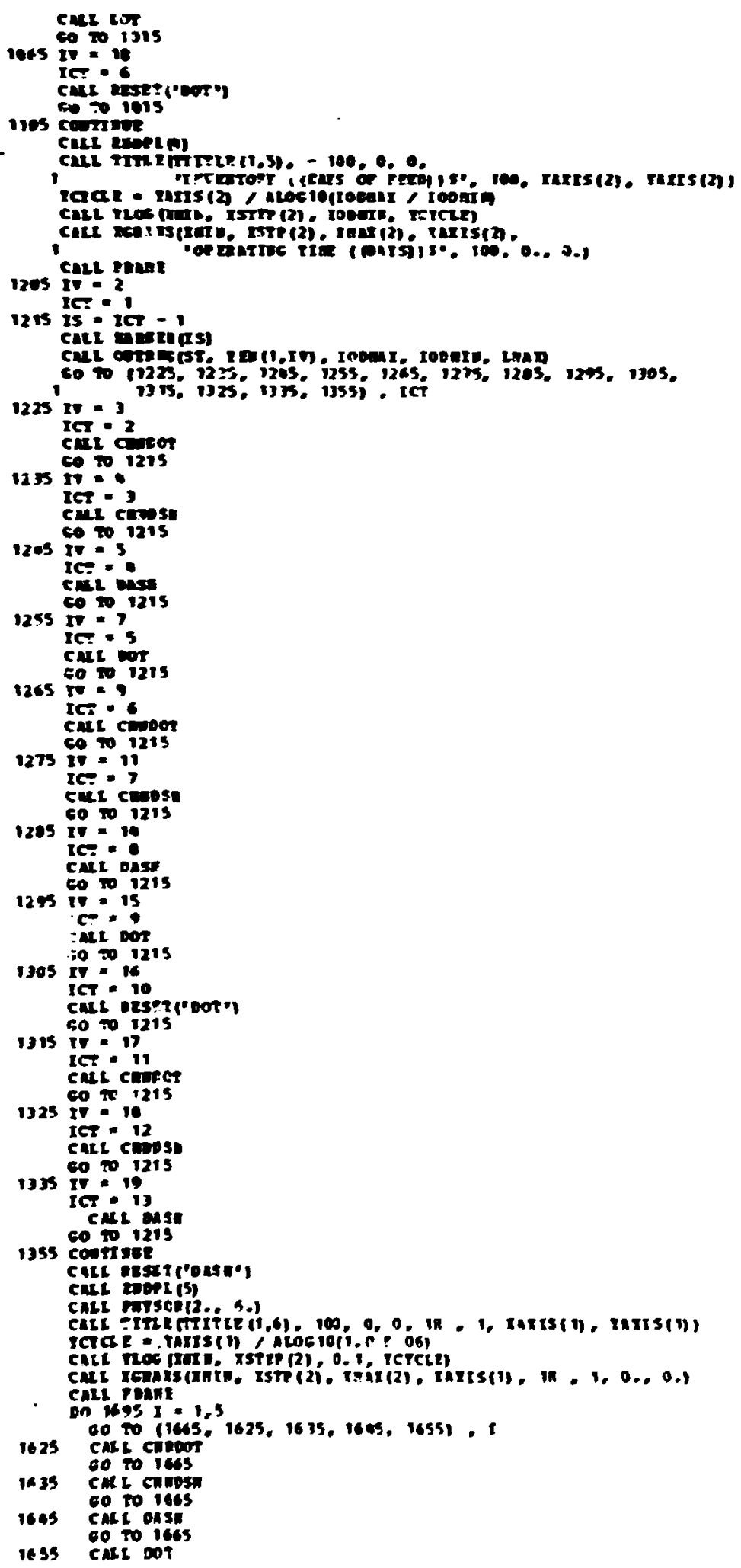




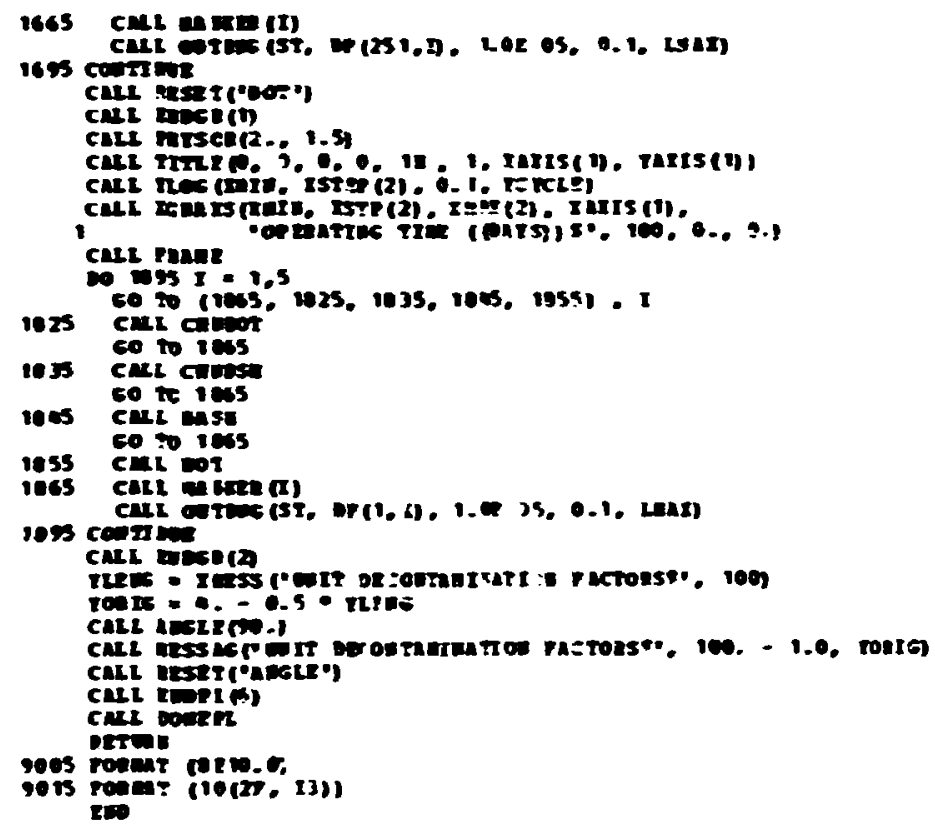




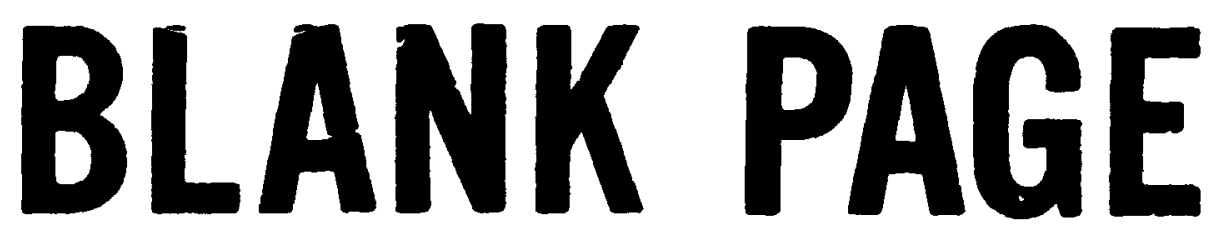


ORI/AURBG-16

Dist. Category uC-4

INERUAL DISTRIBUTTOR

1. R. E. Blanco

2. J. O. Bloweke

3. A. A. Brooks

4. R. E. Brooksbank

5. K. B. Brown

6. W. I. Burch

7. D. 0. Cupbell

8. W. I. Carter

9. H. E. Clark

10. C. F. Coleman

11. D. J. Crouse

12. F. L. Culler

13-47. H. Davis, Jr.

48. R. L. Parrar, Jr., ORGDP

49. G. G. Pee

50. M. L. Pelanan

51. D. E. Ferguson

52. B. C. Finney

53. E. J. Frederick

54. W. Pulkerson

55. R. W. Glass

56. H. H. Godbee

57. H. E. Goeller

58. W. S. Groenter

59. W. O. Harmes

60. F. E. Harrington

61. C. C. Haws

62. R. F. Hitbs

63. A. R. Irvine

64. P. R. Kasten

65. S. V. Kaye

66. O. L. Keller

67. R. E. Leuze

68. K. H. Ifin
69. A. I. Lotts

70. J. C. Mailen

71. A. P. Malireuskas

72. J. D. MeGeugh, Jr.

73. I. E. Mclieese

74. B. Newean

75. K. J. Eotz

76. A. R. 01son

77. H. A. Pruderer

78. H. Postman

79. C. R. Richond

Bo. I. H. Roddy

81. H. H. Rosenthal

8E. C. D. Scott

83. J. H. Snider

84. D. H. Tedder

85. M. L. Tobias

86. D. B. Trauger

87. H. E. Unger

88. P. R. Vanstrum

89. V. C. A. Vaughen

90. B. I. Vondra

91. C. D. Watson

9. R. G. Hywer

93. 0. 0. Yarbro

34. E. I. Gaden, Jr. (consultant)

95. C. H. Ice (consultant)

96. R. B. Richards (consultant)

97-98. Central Research Ifibrary

99. Document Reference Section

100-102. Laboratory Records

103. Laboratory Records - RC

104. ORIL Patent office 


\section{EXTERTAL DISTRIBUTION}

105. R. I. Ashley, Bechtel Dower Corp., P. C. Box 607, Gaithersburg MD 20760

106. A. L. Ayers, Allied General Nuclear Services, P. 0. Box 847, Barrive11, SC 29812

107. S. Beard, Exxon Nuclear Co.. Field Box 3965, San Francisco, CA 94119

108. R. G. Bradley, Energy Research and Development Administration, Hashington, D. C. 20545

109. L. F. Brooks, General Atomic Co., P. O. Box 81608, San Diego, CA $\operatorname{sel} 38$

110. I. I. Burger, Pacific Northwest Laboratory, Box 999, Richland, WiA 99352

111. L. Burris, Jr., Argonne National Laboratory, 9700 S. Cass Avenue, Argonne, II 60439

112. A. B. Carson, Fast Breeder Reactor Development, General Electric Co., San Jose, CA 95100

113. A. T. Clark, U. S. Nuclear Regulatory Comnission, Washington, D. C. 20555

174. B. L. Cohen, Department of Physics, University of Pittsburgh, Pittsburgh, FA 15261

115. J. T. Collins, J. S. Nuclear Regulatory Commission, Washington, D. C. 20555

116. G. W. Cunningham, Energy Research and Development Administraticn, Washington, D. C. ¿20545

117. R. E. Cunningham, U. S. Nuclear Regulatory Comission, Washington, D. C. 20555

118. G. G. Eichholz, Georgia Institute of Technology, School of Fucleer Engineering, Atlanta, GA 30332

119. F. M. Bupson, U. S. Nuclear Regulatory Comission, Washington, D. C. 20555

120. J. F. Fletcher, Hanford Engineering Development Lab., P. O. Box 1970, Richland, WA 99352

121. R. F. Foster, Pacific Northwest Laboratory, Box 999, Richland, WA 99352

122. F. Gera, C.N.E.N., Viale Regina, Margherita 125, 00198, Rome, Italy

123. J. R. Grover, International Atomic Energy Agency, Vienna, A.istria

124. C. A. Heath, Energy Research and Development Administration, Washington, D. C. 20545

125. K. D. B. Johnson, A. E. R. E., Harwell, Didcot, Berks., England

126. R. H. Kennedy, Energy Research and Development Administration, Washington, D. C. 20545

107. I. T. Iakey, Excxon Nuclear Company, Richland, WA 99352

128. S. Langer, Generul Atomic Co., P. 0. Box 81608, San Dfego, CA 92138

129. H. Larroskt, Allied Chemical Corporation, 550 Secnnd street, Idaho Falls, ID 83401

130. M. Ievenson, Electric Power Research Institute, 3412 Hiliview Avenue, PaIo AIto, CA 94304 
131. W. H. Levis, Huclear Fuel Services, Inc., 6000 Bxecutive Blvd., Rockville, M 20852

132-133. J. I. Iiverman, Energy Research and Development Administration, Washington, D. C. 20545

134. H. Iowenberg, U. S. Nuclear Regulatory Comission, Washington, D. C. 20555

135. P. Loysen, U. S. Fuclear Regulatory Comission, hashington, D. C. 20555

136. P. J. Magno, U. S. Nuclear Regulatory Commission, Washington, D. C. 20555

137. B. J. Mann, Envirommental Protection Agency, P. 0. Box 15027, Las Vegas, iv 89114

138-139. J. B. Martin, U. S. Nuclear Regulatory Commission, Washington, D. C. 20555

140. D. R. Miller, Energy Research and Development Administration, Washington, D. C. 20545

14.1. W. A. Mills, Envirommental Protection Agency, Waterside Mall, Washington, D. C. 20460

142. H. A. C. McKay, A.E.R.E., Harwell, Didcot, Berks., England

143. R. I. Newman, Allied General Nuclear Services, P. O. Box 847 , Barnwell, SC 29812

144. A. M. Platt, Pacific Northwest Iaboratory, Box 999, Richland, WA 99352

145. G. B. Pleat, Energy Research and Development Administration, Washington, D. C. 20545

146. R. G. Post, Department of Nuclear Engineering, University of Arizona, Tuscon, AR 85721

147. A. J. Pressesky, Energy Research and Development Administration, Washington, D. C. 20545

148. Research and Technical Support nivision, Oak Ridge Operations

149. A. D. Riley, Allied Chemical Corporation, P. 0. Box 430, Metropolis, IL 62960

150. A. P. Roeh, Allied Chemical Corporation, 550 Second Street, Idaho Falls, ID 83401

151. W. A. Rodger, Nuclear Safety Associates, 5101 River Rd., Bethesda, MD 20016

152-155. L. C. Rouse, U. S. Nuclear Regulatory Commission, Washington, D. C. 20555

156. W. D. Rowe, Environmental Protection Agency, 401 M. Street, S. W., Washington, D. C. 20460

157. J. Schacter, General offices, Union Carbide Nuclear Division, Oak Ridge, TN 37830

158. A. Schneider, Georgia Institute of Technology, School of Nuclear Engineering, Atlenta, GA 30332

159. K. J. Schneider, Pacific Northwest Laboratory, Box 999, Richland, WA 39352

160. J. M. Selby, Pacific Northwest Laboratory, Box 999, R'.chland, WA 99352

161. J. J. Snefcik, General A.tomic Company, P. O. Box 8160'3, San Diego, CA 92138 
162. G. I. Simmons, Science Applications, inc., 1200 Prospect street, La Jolla, CA 92037

163. C. M. Slansky, Allied Cherical Cort., 55C Second Street, Idaho Falls, ID 83401

164. B. I. Spinrad, Radiation Center, Oregon State University, Corvallis, OR 97331

165. H. E. Stelling, Energy Research anc Development Administration, Washington, D. C. 20545

166. C. E. Stevenson, Argonne Mational Laboratory, 9700 S. Cass Are., Argonne, IL 60439

167. M. J. Szulinski, Science Applications, Inc., Richland, Wh 99352

168. R. C. Vogel, Exxon Nuclear Company, Inc., Rỉchland, WA 99352

169. W. R. Voight, Energy Research and Fevelopment Administration, Washington, D. C. 20545

170. B. F. Warner, U.K.A.E.A., Windscale and Calder Works, Sellafield, Seascale, Cumberland, Enzland

171. A. M. Weinberg, Oak Ridge Assoclated Universities, Oak Ridge, TiI 37830

172. W. Wefnlander, GFK - Institute f. Hefsse Chemie, Postbox 3640, D7500, Karlsruhe, West Germany

173. A. K. Williams, Allied General Nuclear Services, P. O. Box 847, Barnwe11, SC 29812

174-374. Given distribution as shown in TID -4500 under Category UC-4 